Article

\title{
The Sedimentary Origin of Black and White Banded Cherts of the Buck Reef, Barberton, South Africa
}

\author{
Morgane Ledevin, Nicholas Arndt *, Catherine Chauvel $\mathbb{D}$, Etienne Jaillard and \\ Alexandre Simionovici (D) \\ ISTerre, University Grenoble Alpes, 38400 Grenoble, France; morgane.ledevin@gmail.com (M.L.); \\ catherine.chauvel@univ-grenoble-alpes.fr (C.C.); ejaillar@univ-grenoble-alpes.fr (E.J.); \\ alexandre.simionovici@univ-grenoble-alpes.fr (A.S.) \\ * Correspondence: nicholas.arndt@univ-grenoble-alpes.fr; Tel.: +33-640-599-095
}

Received: 28 July 2019; Accepted: 20 September 2019; Published: 1 October 2019

\begin{abstract}
The Buck Reef is a $250-400 \mathrm{~m}$ thick sequence of banded black and white (B\&W) cherts deposited ca. $3416 \mathrm{Ma}$ ago in a shallow basin. We provide field, petrological and geochemical constraints on the chert-forming process and the origin of the banding. White layers consist of nearly pure microquartz, while black layers are mixed with detrital carbonaceous matter, quartz grains and carbonaceous microlaminae, interpreted as remnants of microbial mats. The circulation of Si-rich fluid is recorded by abundant chert veins and pervasive silicification. However, the high purity of the white layers, their lack of internal structures and extremely low $\mathrm{Al}$, Ti and high-field-strength elements preclude an origin by silicification of sedimentary or volcanic precursors. Moreover, their reworking at the surface into slab conglomerates, and sediment-like contacts with black layers rule out a diagenetic origin. We propose a new model whereby the white layers were periodically deposited as precipitates of pure silica; and the micro-layering within the black layers formed by annual temperature fluctuations, favouring microbial activity in summer and inorganic silica precipitation in winter. Outcrop-scale alternation of B\&W layers was associated with major, thousand-year-long climate events: white cherts represent massive silica precipitation resulting from changes in ocean circulation and temperature during cold intervals.
\end{abstract}

Keywords: chert; Archean; Buck Reef; sediment; geochemistry; climate

\section{Introduction}

Banded cherts and iron formations are widespread in Precambrian sediment. In both types of sediment, bands of nearly pure, white or beige-coloured silica alternate with darker bands of carbonaceous, iron-rich, carbon-rich siliceous or detrital sediments (e.g., [1-3]).

Several hypotheses have been proposed to explain the banding: (1) inheritance from a bedded sedimentary or volcanosedimentary precursor now silicified to chert [4-6]; (2) diagenetic segregation of individual bands from a homogeneous mixture of silica and other components [2,7], and (3) primary deposition of alternating ferruginous/carbonaceous and pure silica sediments, with a periodicity controlled by cyclic volcanic activity and/or periodic upwelling in a stratified ocean (e.g., [8-12]), or by climate-induced temperature variations [13].

The origin of layers of almost pure silica is important because these layers represent our best chance to determine the composition of precipitating fluids and our best access to the Archean near-surface environment. A common approach is to compare the trace-element composition of the cherts with those of modern seawater and hydrothermal fluids, and on this basis to decide on the nature of the source (e.g., [1,14-16]). In addition, the $\mathrm{Si}$ and $\mathrm{O}$ isotopic compositions of cherts provide insights on the origin of the silica and/or past ocean temperatures [12,17-24]. 
However, before the compositions of banded deposits can be used as paleo-environment proxies, several key issues must be resolved: how did they form and what is the origin of the banding? What is the trigger of silica precipitation and what is the origin of nearly pure silica layers? This study addresses these questions using the Buck Reef, a well-known sequence of black and white cherts from the Barberton Greenstone Belt, South Africa. Using field, petrologic and geochemical criteria, we constrain the origin of the cherts and develop a novel model that explains the nature of the involved fluids, the mechanisms of silica precipitation and the origin of the banding.

\section{Geological Context}

The Barberton Greenstone Belt (3.57-3.21 Ga) is a well-preserved, 12-15 km thick volcano-sedimentary succession that encompasses about 320 Ma of early Earth history (see, e.g., [25-30] for geological context).

The Buck Reef Chert (3416 Ma, [27]) is a thick siliceous sedimentary unit that crops out continuously for more than $30 \mathrm{~km}$ along the west limb of the Onverwacht anticline (Figure 1a) [2,7]. It is located above shallow water, intrusively to extrusive dacitic volcanic rocks and volcaniclastic units of the Hooggenoeg Fm. (Figure 1b) [5,6,25,30-34]. At the base, the volcaniclastics are dacite-derived conglomerate and sandstones, interpreted by Lowe and Fisher Worrell [7] as coastal or braidplan deposits. They were deposited during extension, as revealed by numerous listric normal faults [6], and are conformably overlain by $250-400 \mathrm{~m}$ of black and white banded cherts. As shown in Figure 1c, the sequence starts with evaporitic facies of silicified sandstones, cherts and nahcolite pseudomorphs deposited in a shallow-water, lagoonal environment $[2,7]$. The overlying 200-300 m records a gradational transition from detritus-rich black and white banded cherts marked by medium- to low-energy current structures, to continuous, finely-laminated cherts; that recoded deposition being under quieter conditions, away from coastal turbulence [2]. The banded carbonaceous cherts evolve upward through banded ferruginous cherts to a capping unit of sandstone and siltstone.
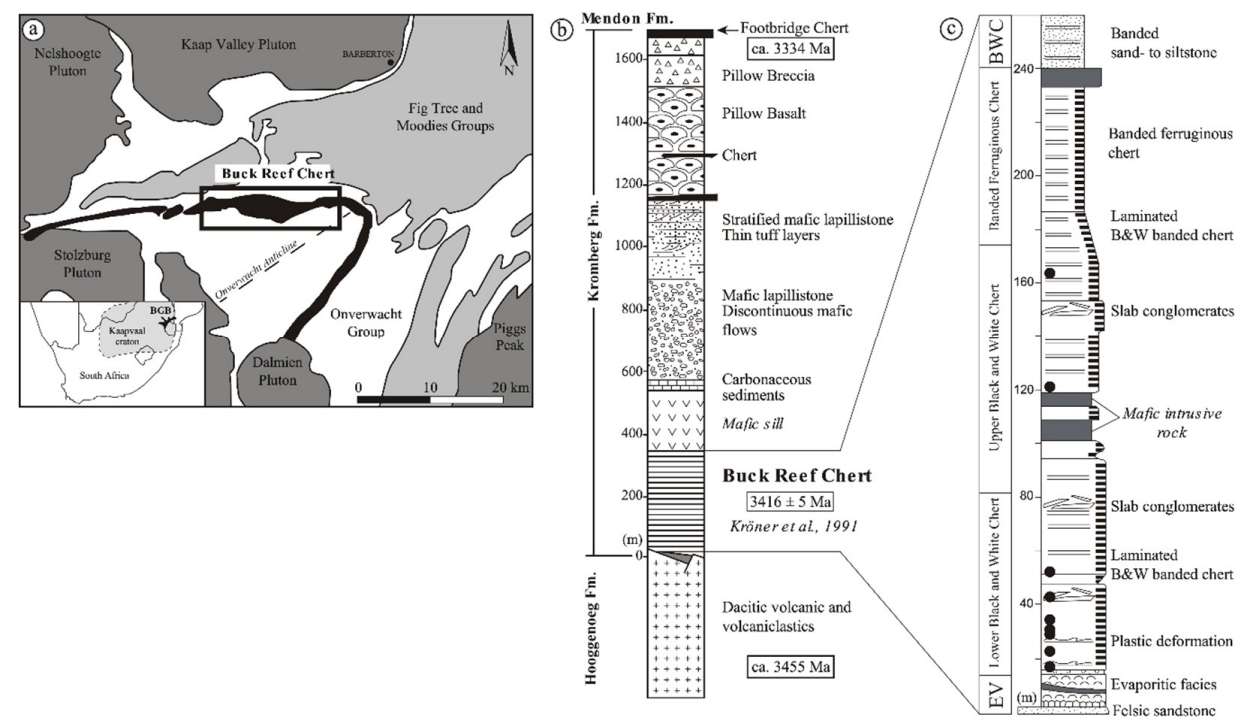

Figure 1. (a) Simplified geological map of the Barberton Greenstone Belt, South Africa. Stratigraphy of (b) the Hooggenoeg to Kromberg Formation transition and of (c) the Buck Reef Chert, modified from Lowe [34] and Tice and Lowe [2], respectively. The Buck Reef sequence is a 250-400 m-thick unit of black and white $(B \& W)$ banded cherts overlying dacitic volcaniclastics and volcanic rocks from the Hooggenoeg Fm. The evaporitic to $B \& W$ to ferruginous banded chert transition reflects a deepening of the basin [2]. Black circles represent samples location.

The banded cherts were deposited in a setting where continent-derived detritus was rare, favouring chemical sedimentation driven by oceanic processes. Lowe and Byerly [7] and Tice and Lowe [2] 
proposed that the sequence accumulated on a subsiding platform, with conditions evolving from a shallow coastal lagoon to a shelf-like setting, then to open-ocean deeper basinal conditions. De Vries et al. [5] argued instead that the whole unit is a transgressive sequence deposited under shallow water conditions, close to base level, and evolved from a lagoon-like setting with local emersion to a littoral setting. The presence of microfossils and microbial mats in the Buck Reef Chert [2,35-37], and the unusual thickness and excellent exposure of the banded chert sequence, make this an area of special interest.

\section{Field Descriptions}

This study focuses on the well-developed banded chert units forming the core of the sequence; i.e., the lower and upper units of black and white chert in Figure 1b. The banding consists of alternating and equally abundant black carbonaceous chert and white-weathering translucent chert (Figure 2a,b). The thickness of the bands decreases up the section, from 5-10 cm in the lower unit to $<5 \mathrm{~cm}$ on average in the upper unit. The black chert bands in the lower unit contain light-grey, fine-grained particles ( $<1 \mathrm{~mm}$ in average) that lie in a siliceous translucent matrix (Figure $2 \mathrm{~b}$ ) and preserve thin laminations and current-induced structures, such as ripple marks and cross-laminations. Higher in the section, black cherts contain fewer particles, with few to no sedimentary structures, and have pale rusty-weathering colours, revealing the presence of ferruginous components. White chert layers are almost entirely composed of massive, homogeneous, finely crystallized silica (Figure 2a,b). They lack obvious detrital grains, iron oxides and other impurities, and even sedimentary structures. In places, sub-rounded white chert fragments can be found in the adjacent black chert.
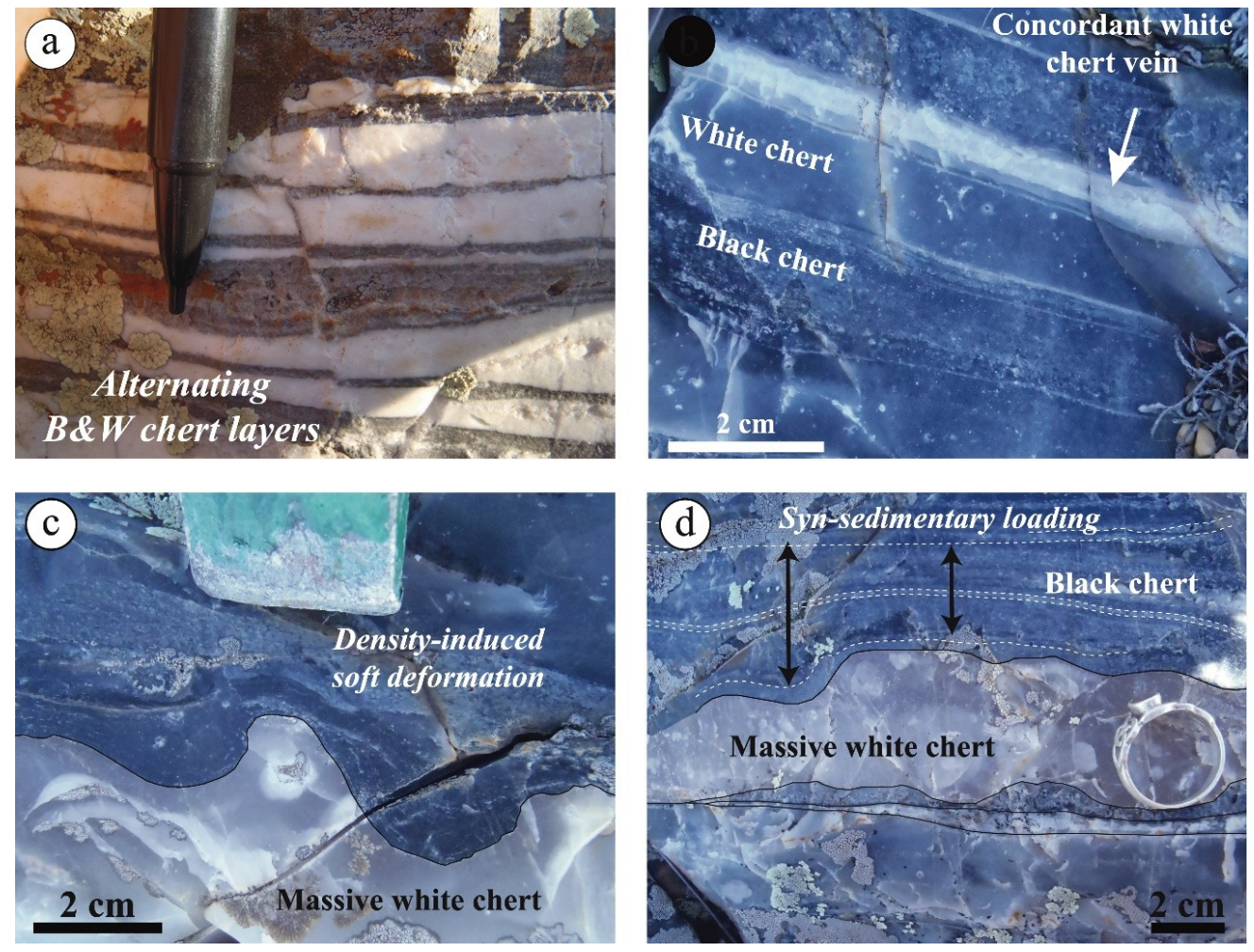

Figure 2. (a) Weathered and (b) fresh outcrops of typical banded cherts' facies showing regular alternations of particle-rich, thinly laminated black chert with particle-free, white chert. (b) Example of concordant white chert veins of well-crystallized quartz with colloform structures. (c,d) The top a of white layer is commonly soft-deformed underneath a denser black chert band. (c) The contact is sharp but undulating in a way similar to load-cast structures. (d) Thin laminations in the overlying black chert follow the undulations, then become regular and undeformed a few centimeters away from the contact. 
Contacts between layers of white and black chert are sharp and frequently undulating (Figure 2c,d). In Figure $2 \mathrm{~d}$, the laminations in the overlying black facies are disturbed close to the undulations but become regular and undeformed within 1-3 cm of the contact. Undulation troughs lack obvious onlaps or fan-like sedimentary structures, indicating that the deformation was not syn-sedimentary but occurred by density contrast during very shallow burial, soon after the deposition of black chert onto still soft and deformable white chert.

Distinctive "slab conglomerates" alternate with the regular banding (Figure 3a) within the lower unit. These layers reach $1-2 \mathrm{~m}$ in thickness (generally $<50 \mathrm{~cm}$ ) and commonly disappear laterally after several meters. They consist of elongated slabs of white chert, typically 2 to $50 \mathrm{~cm}$ long and 1 to $10 \mathrm{~cm}$ thick, in a matrix of grey to black chert. The upper contacts of conglomerate beds are irregular due to the disposition of the slabs, and the overlying detritus has rich, black chert filled troughs with typical fan structures, as shown in Figure 3b. At the lower contact (Figure 3c), fluid-escape structures point to conglomerate deposition on a still soft and hydrated substratum.
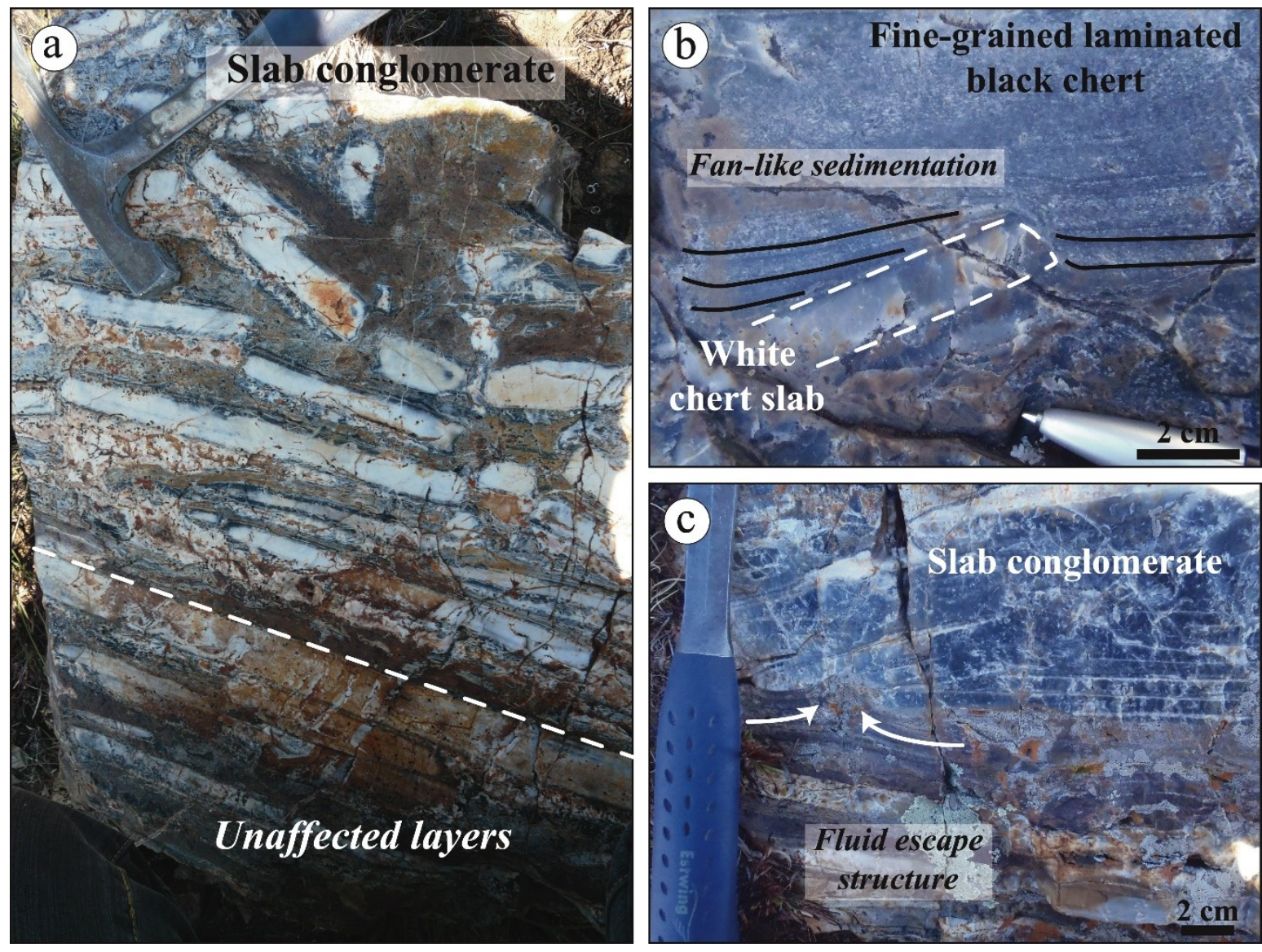

Figure 3. (a) Slab conglomerates consist of elongated white chert slabs in a black chert matrix. Slabs are parallel, then slightly inclined (typically $>10^{\circ}$ ) to undisrupted layers. (b) and (c) show evidence for seafloor deposition of slab conglomerates: (b) fan sedimentation and onlap structures developed as thinly laminated black chert deposited onto the irregular surface of the conglomerate; (c) load-induced fluid escape structure formed at the bottom after the conglomerate emplaced onto a poorly lithified siltstone.

The slabs and interstitial material are lithologically similar to undisrupted white and black chert layers, respectively (Figures 3 and 4), and no conglomerates consist of black chert slabs in a white chert matrix. The fragments are usually oriented at angles of less than $10^{\circ}-15^{\circ}$ to the bedding, but in some examples, are strongly disrupted and oriented at higher angles. The slabs are elongated with angular to rounded margins (Figure 3a), indicating they were rigid at the time they were disrupted. In contrast, 
the black matrix shows systematic plastic deformation, highlighted by flowage of the detrital material around chert fragments (Figure 4a). In places, part of the matrix consists of well-crystallized quartz that resembles cavity-filling textures (Figure $4 \mathrm{c}$ ).
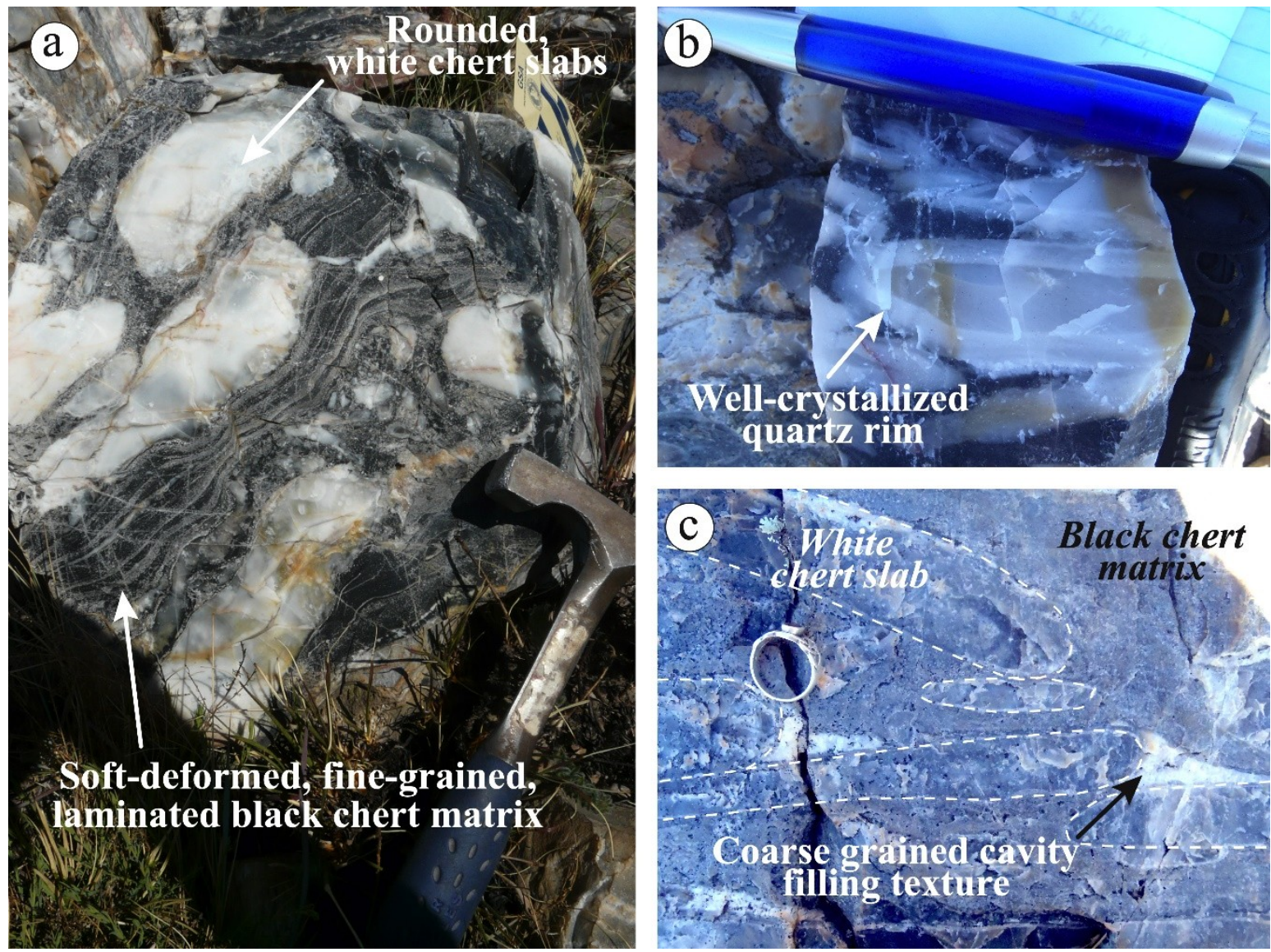

Figure 4. Details of slab conglomerates showing: (a) rounded white chert deposited in a soft deformed, fine-grained and laminated black chert matrix; (b) angular white chert slabs with a well-crystallized quartz aureole; (c) elongated white chert slabs and void-filling silica textures in a fine-grained black chert matrix.

Parts of the Buck Reef cherts were affected by strong silicification after deposition, as shown by abundant white chert veins or fractures and the presence of silicification fronts that affected internal structures of some black cherts. White veins cut across both white and black chert facies at very low angles (e.g., Figure 2b); they can be traced only over small distances along outcrops and vary in thickness from $<1 \mathrm{~mm}$ to $20 \mathrm{~cm}$. They are distinct from massive white layers in that they are well crystallized and coarser grained, commonly with colloform structures. Silicification fronts, on the contrary, are pervasive and transgress either homogeneously (Figure 5a) or randomly (Figure 5b) across the layering. The latest stage of silica mobilization occurred via pressure-dissolution processes during deep burial, as expressed by the abundance of stylolites (Figure 5a). 

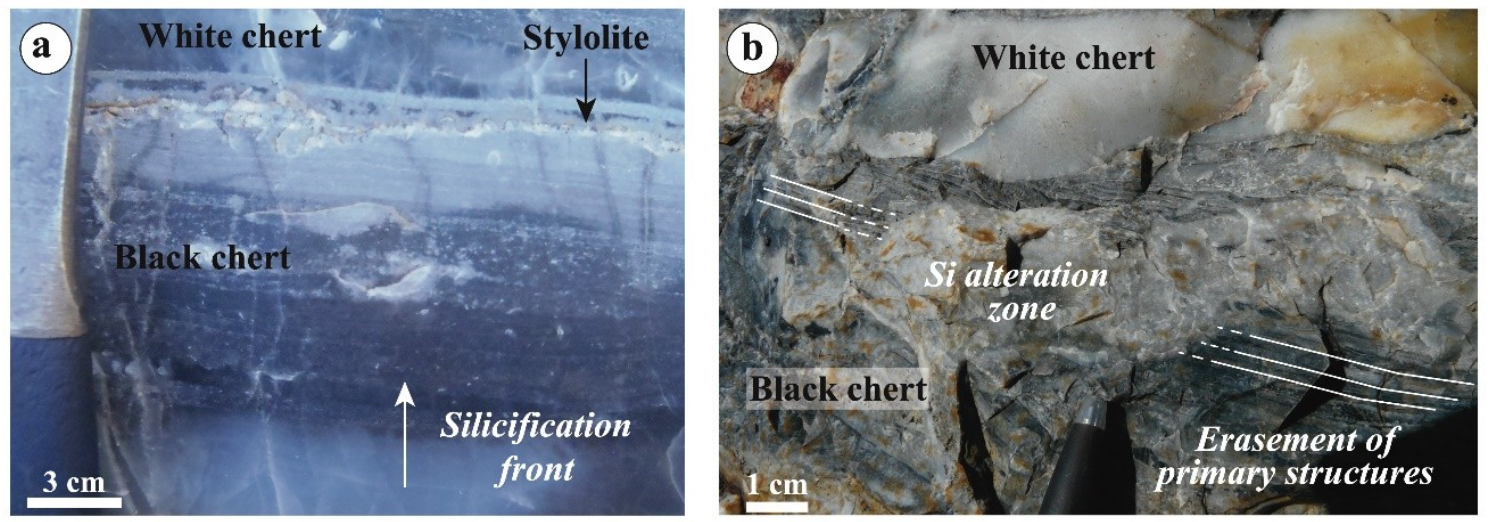

Figure 5. Silicification and fluid circulation features within the Buck Reef cherts. (a) Thinly laminated, black to light grey chert affected by diffuse silica migration, perpendicular the to bedding: disappearance of internal structures behind a white, semi-translucent color. (b) Black chert with internal laminations (highlighted in white) is partially erased by a well-developed silica alteration zone.

\section{Sample Selection and Description of Thin Sections}

Based on the assumption that the white, detritus-free chert layers are most likely to represent primary precipitates, we collected five samples at interfaces with surrounding black cherts. An additional 11 samples were taken from massive black chert layers, white chert veins, and slab conglomerates.

\subsection{White Chert Facies}

Massive translucent white chert bands are entirely composed of equigranular microcrystalline a-quartz (> 99\%) with individual grains $<5-10 \mu \mathrm{m}$ in size (i.e., microquartz) (Figure $6 \mathrm{a}, \mathrm{b})$. These grains have irregular, crenulated boundaries and sweeping extinctions (Figure 6b). The closely intergrown framework contains little porosity, and internal sedimentary structures are lacking. Minute grains $(<1 \mu \mathrm{m})$ of chromite and iron oxide are disseminated within the microquartzitic matrix and rare ankerite and siderite grains occur as secondary phases associated with $\mathrm{mm}$ - to $\mu \mathrm{m}$-thick silica-veins (Figure 6c,d). Minor iron oxides (e.g., hematite), siderite and stilpnomelane occur as secondary minerals in white cherts in the upper ferruginous part of the sequence. 

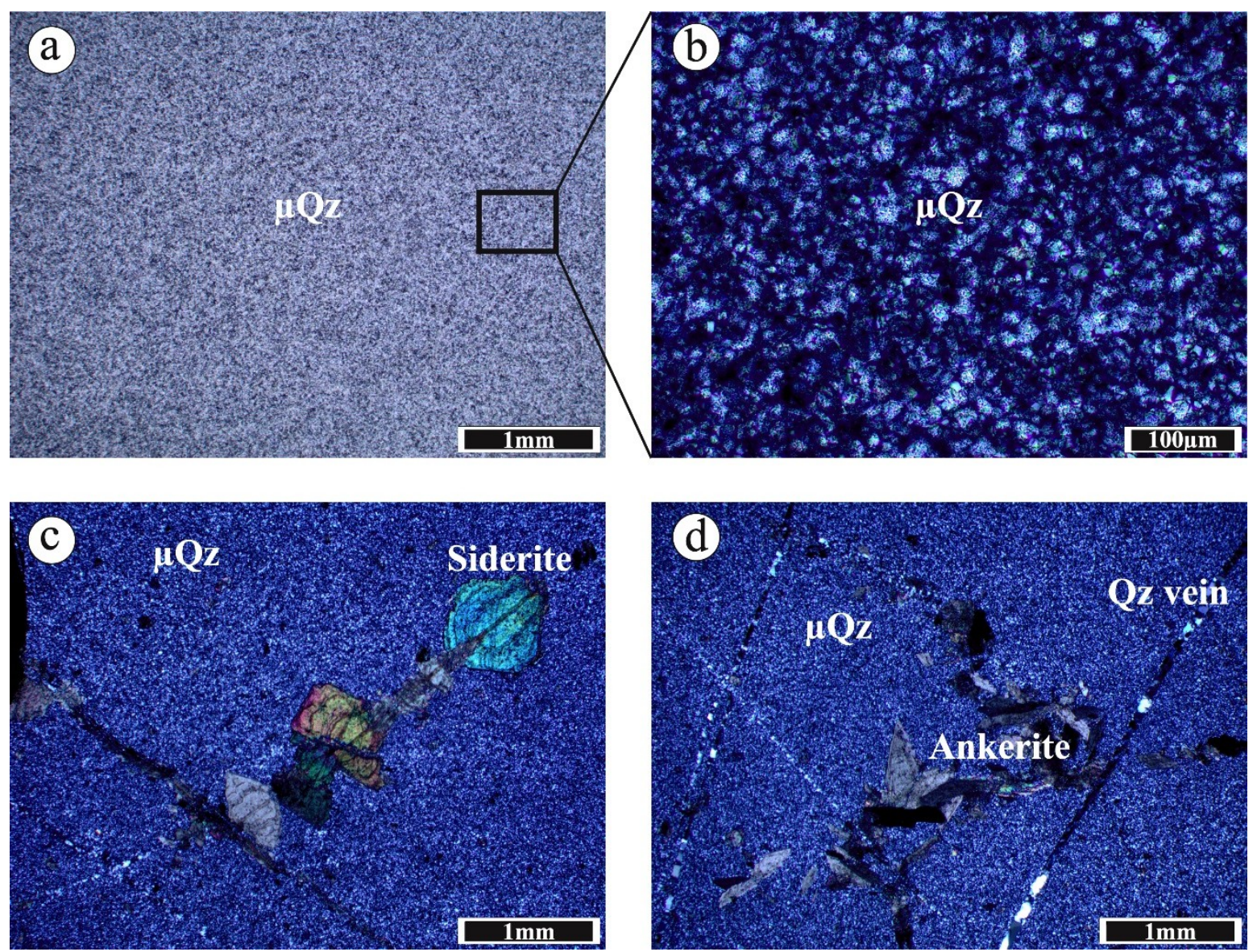

Figure 6. Optical microscopy for massive white chert samples. $\mu \mathrm{Qz}=$ microquartz. (a) and (b) show the purity and homogeneity of massive white chert. They are entirely composed of microquartz of 5 $\mu \mathrm{m}$ in average size. (c) and (d) All layers are cross-cut by thin quartz-filled veins $(<0.5 \mu \mathrm{m})$ commonly associated with siderite (c) and ankerite (d) secondary minerals.

White chert veins, irrespective of their thickness, have diffuse and irregular (Figure 7) or sharp (Figure 8) contacts with surrounding rocks; they commonly cut across internal structures of surrounding chert layers. A typical internal organization (Figure 7) consists of microquartz at the margin, through a zone with chalcedony-like textures, to coarsely crystalline quartz in the centre. The quartz crystals are up to $1 \mathrm{~mm}$ long and are commonly aligned perpendicular to the contact. The central parts of these veins often contain siderite or ankerite grains that are intergrown with macroquartz crystals and represent the final crystallization product. 


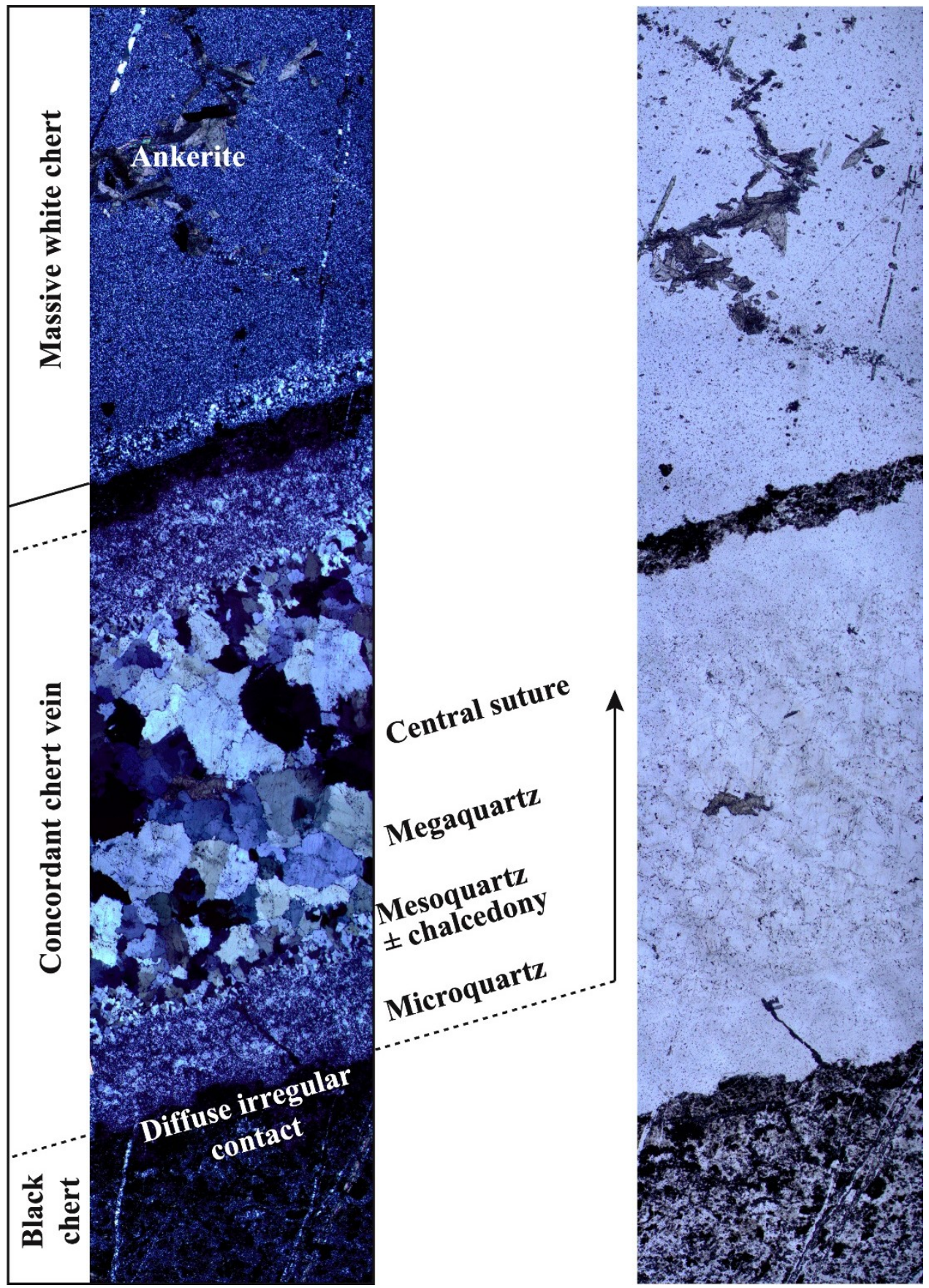

Figure 7. Natural (right) and polarized (left) photomicrographs showing the petrologic evolution from a massive black chert (base) to massive white chert (top), with an intermediate concordant quartz-filled vein. The vein displays a specific internal organization: at the contact, it comprises microquartz that evolves to mesoquartz and megaquartz when going towards the center. The micro- to megaquartz transition is abrupt over less than $0.2 \mathrm{~mm}$.

\subsection{Black Chert Facies}

The massive black cherts are more heterogeneous. They contain abundant and morphologically diverse types of carbonaceous matter (Figures 8 and 9) in association with variable quantities of sandto silt-sized particles that are interpreted as detrital quartz grains (Figures 8 and 9a). Carbonaceous matter occurs as (1) rounded and undeformed agglomerates (up to $1 \mathrm{~mm}$ ) with well-defined boundaries (Figure 8$) ;(2)$ homogeneous grains $(<0.5 \mathrm{~mm})$ usually elongated along a bedding plane 
(Figures 8 and 9b) and commonly coated with clear, Si-rich zones (Figure 9b); and (3) thin laminations and films trapped within the silicified sediments $(<10-15 \mu \mathrm{m}$ thick) (Figure 8). Carbonaceous matter comprises up to about $20 \%$ of the black chert, the rest being microcrystalline quartz $(<5 \mu \mathrm{m})$.
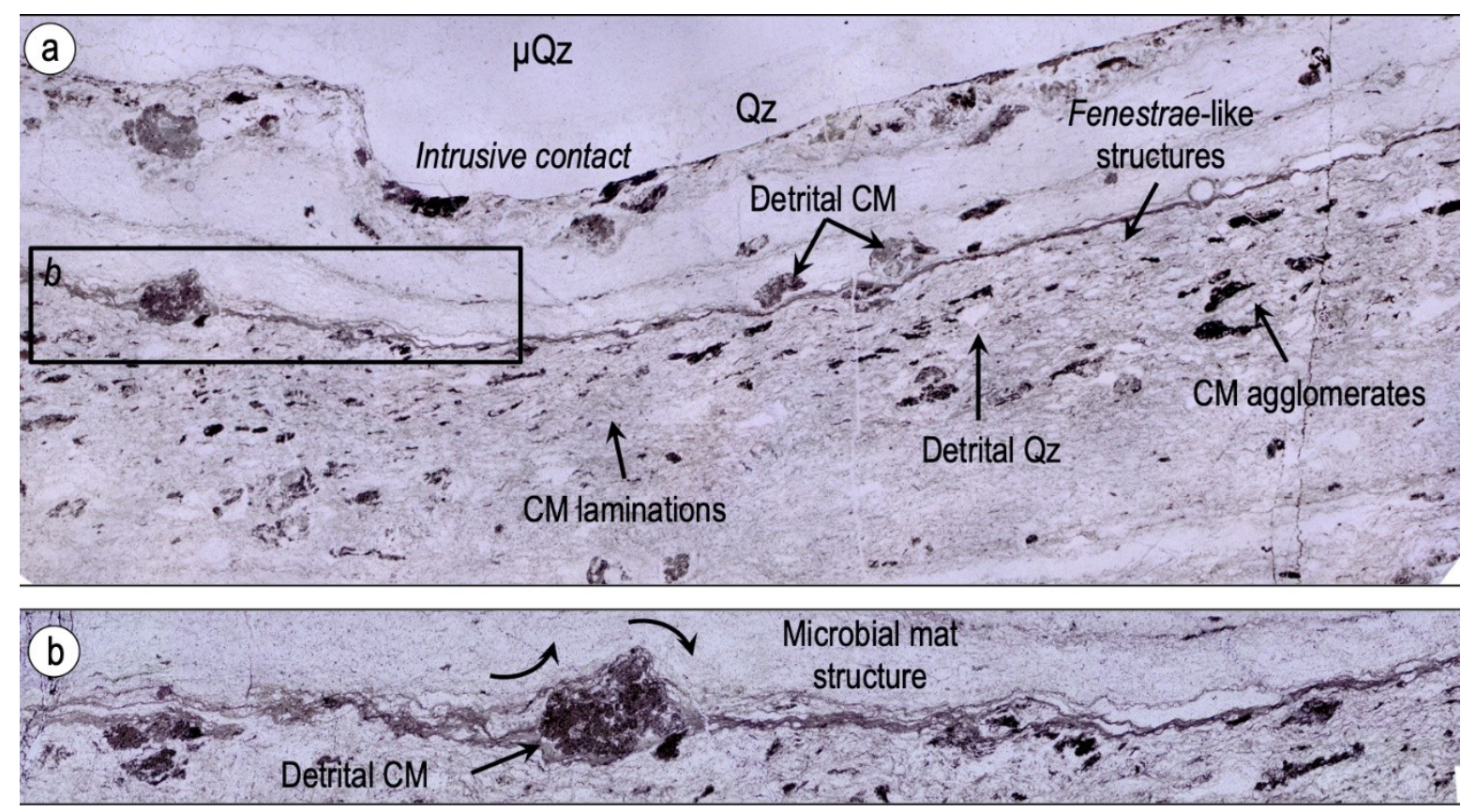

Figure 8. Massive black chert layer from the lower part of the Buck Reef. The top is truncated by a white chert vein. Image (b) is a detail of (a). The chert contains detrital rounded grains, elongated agglomerates and thin laminations of carbonaceous matter in a microquartzitic matrix. (b) Thin laminations draping detrital carbonaceous grains in a way similar to modern microbial mats. $\mathrm{CM}=$ Carbonaceous matter; $\mu \mathrm{Qz}=$ microquartz; $\mathrm{Qz}=$ Quartz.

Thin carbonaceous laminations are characteristic of black cherts from the shallow-deposited layers in the lower unit They alternate at the micrometre scale with pure, finely crystallized silica layers $<10-15 \mu \mathrm{m}$ in thickness. In Figure 8, the structures can be followed laterally with laminations characterized by irregular undulations, dome-like shapes and local detachments or fenestrae filled by microquartz. This structure strongly resembles microbial mat remnants fossilized in a microquartzitic matrix, like those observed by Walsh [35], Tice and Lowe [2] and Westall [36]. Sand- to silt-sized detrital particles, either ghosts of rounded grains now recrystallized to microquartz or carbonaceous grains, are commonly trapped within and draped by these thin layers (Figure 8b), which is interpreted to record microbial growth in a detrital environment (e.g., [38]).

Fine biogenic laminations are absent in black cherts from the upper unit (Figure 9a). Here, carbonaceous material is massive, homogeneous and concentrated between whitish microquartzitic zones. The highly irregular shape and very fine-grained texture of most of the whitish zones are inconsistent with a detrital or fenestrae origin, although some detrital quartz grains are observed (Figure 9a). Instead, the texture resembles sedimentation/compaction structures in a heterogeneous, mud-like sediment composed of a carbonaceous and silica mixture. 

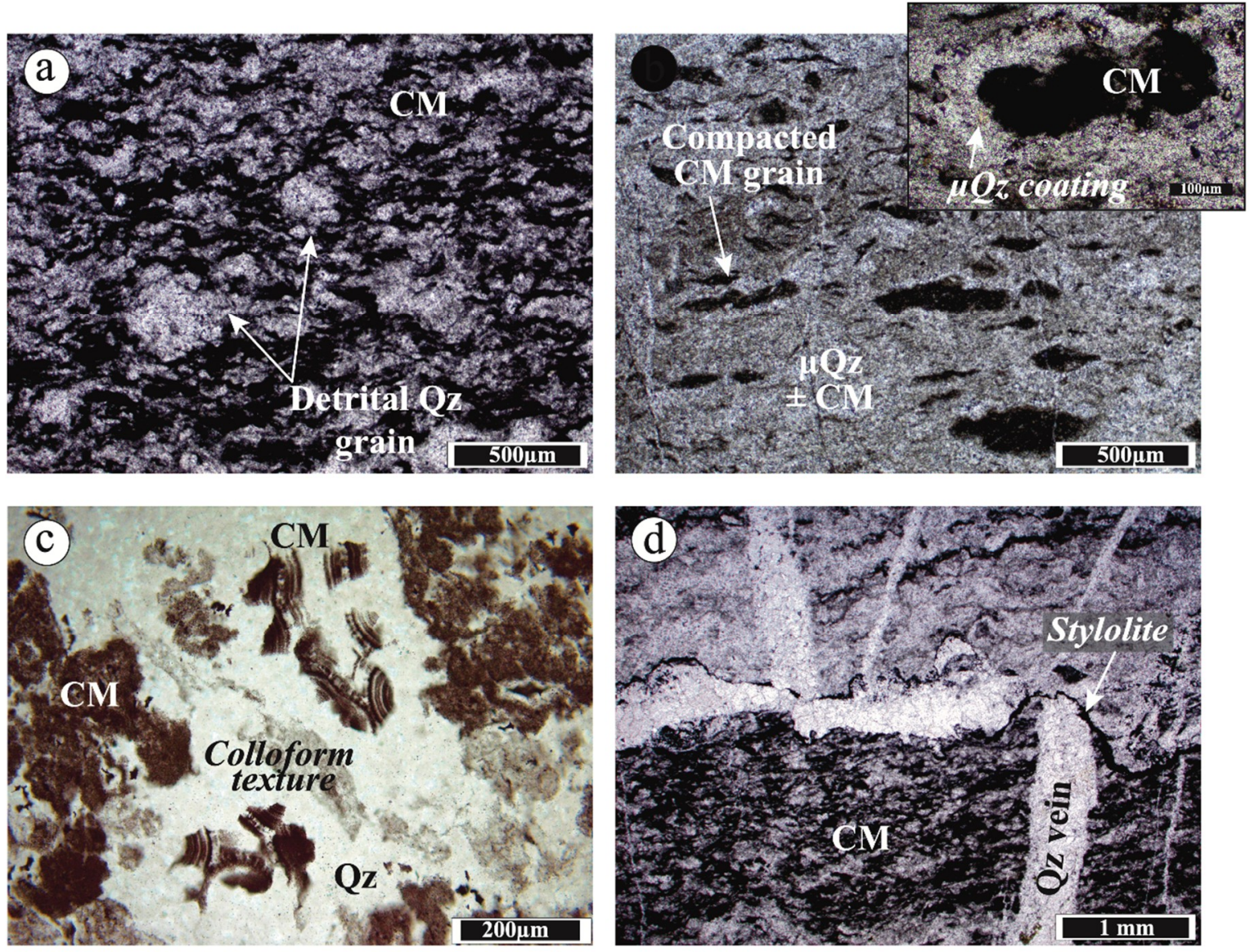

Figure 9. (a) and (b) Photomicrographs of massive black cherts from the top of the Buck Reef sequence: microbial mat structures are absent and the chert consists of a variably packed mixture of microquartz and diffuse carbonaceous matter with trapped detrital carbonaceous grains and ghosts of detrital quartz grains. A close up (b) shows the typical microquartz coating around detrital carbonaceous grains. (c) Partial silicification within the core of a black chert layer: primary textures are erased and carbonaceous matter is locally redistributed along newly formed colloform textures. (d) Stylolites emplaced at the boundary between variably packed zones within a black chert. The stylolite affects chert veins and represents the latest stage of Si-rich fluid migrations $(\mathrm{CM}=$ Carbonaceous matter, $\mu \mathrm{Qz}=$ microquartz, $\mathrm{Qz}=$ Quartz).

Within the core of the black chert layers, primary textures can be partially erased behind pervasive silicification fronts (Figure 9c), especially in the lower part of the lower unit. In Figure 9c, carbonaceous matter is locally redistributed, and concentrated at neo-formed crystal edges, thus highlighting the colloform texture. It is difficult to judge the extent of silicification, but we estimate that it affected about $10-30 \%$ of the outcrop. Further silicification occurred in the form of numerous generations of chert veins (Figures 6-10), themselves affected by stylolites (Figure 9d) which record the latest stage of silica migration.

\subsection{Slabs and Matrix in Slab Conglomerates}

The lithology and texture of the white chert slabs strongly resemble massive white layers; they consist entirely of homogeneous quartz that varies little in grain size, from microquartz $<5 \mu \mathrm{m}$ to mesoquartz up to 20-30 $\mu \mathrm{m}$ (Figure 10a,b). Carbonaceous matter is nearly absent within fragments but is commonly concentrated along their rims (Figure 10b). 

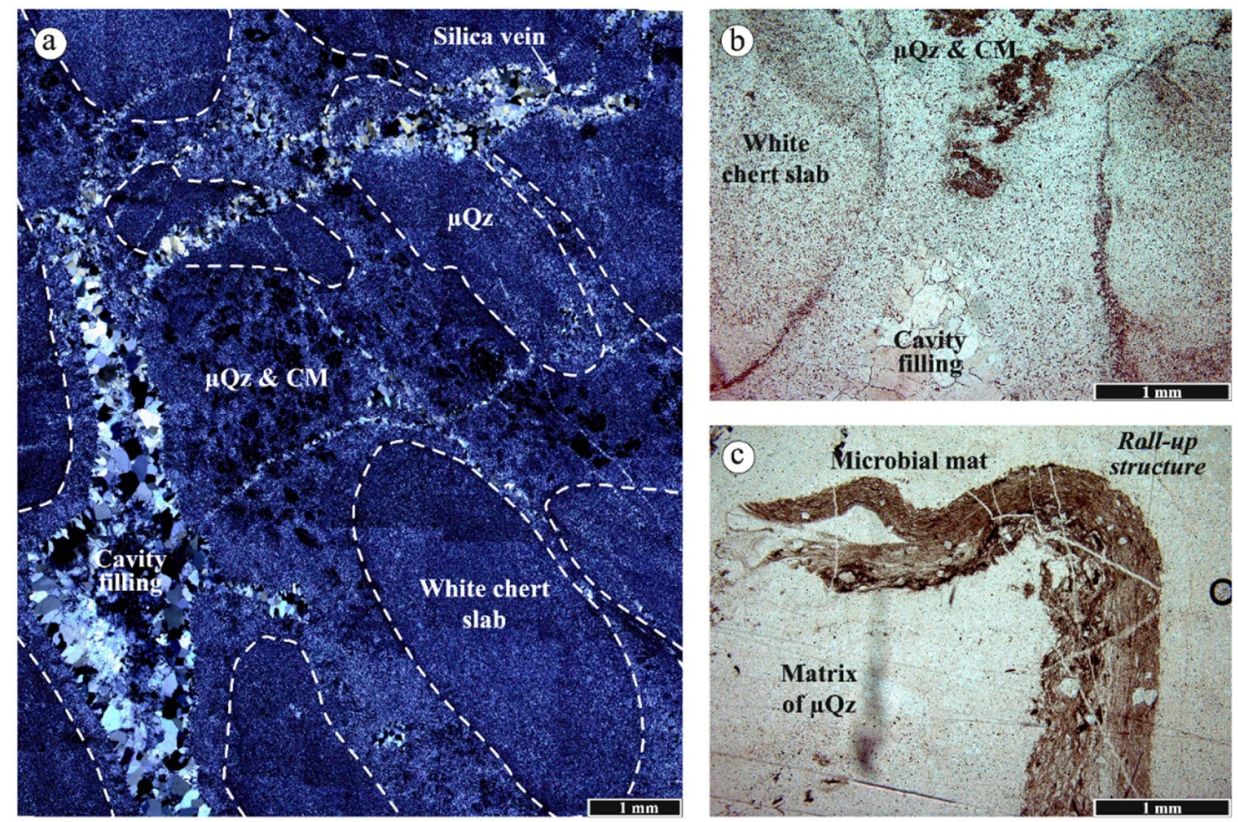

Figure 10. Optical microscopy of a slab conglomerate with slabs highlighted by white dotted lines. (a,b) Slabs are sub-rounded and consist of pure micro to mesoquartz $(<2 \mu \mathrm{m}$ to $<20 \mu \mathrm{m})$ with their border commonly outlined by carbonaceous matter concentrations. The matrix is made of microquartz with a variable amount of carbonaceous matter. Part of the matrix shows cavity-filling texture: microquartz in contact with slabs that may conserve traces of chalcedony. Then, macroquartz when going away from chert fragments is visible. (c) Remarkable example of a microbial mat fragment softly deformed with a roll-up structure and local detachment at the interface between a packed outer zone and a less packed inner zone. $(\mathrm{CM}=$ Carbonaceous matter, $\mu \mathrm{Qz}=$ Microquartz $)$.

The black matrix is very similar to massive black chert layers. Carbonaceous matter is abundant (Figure 9a,b), both as detrital rounded particles or carbonaceous aggregates, and the surrounding matrix is essentially composed of microquartz $(<5 \mu \mathrm{m})$. Rare pieces of microbial mat are preserved as thin, discontinuous laminations. In Figure 10c, a well-preserved piece of mat displays a roll-up structure typical of biofilms reworked when still alive.

Part of the matrix is devoid of carbonaceous matter and shows void-filling textures (Figure 10a) typical of silica precipitation from Si-rich fluids circulating in cavities left between the slabs. Towards the centre of each cavity, the crystal size abruptly increases from $<5 \mu \mathrm{m}$ to $1 \mathrm{~mm}$ and large chalcedony grains (up to $2 \mathrm{~mm}$ ) and colloform textures may be preserved. Numerous chert veins ( $<1 \mathrm{~mm}$-thick) cross cut both the slab and matrix in conglomerates (Figure 10a) and are further evidence of secondary fluid infiltration in those layers.

\subsection{Contacts between Black and White Layers}

Contacts between black and white layers are sharp, with small-scale irregularities (Figure 11c,d), dome-like structures (Figure 11a) and/or small-scale load cast structures (Figure 11c) that resemble syn-sedimentary, soft-deformation structures. Internal structures in the black chert strata, interpreted as biogenic laminations or abiological structures, generally follow the contacts with surrounding white chert layers (Figure 11a). Concentrations of carbonaceous matter (Figure 11c) or more densely packed carbonaceous laminae (Figure 11b,d) are common at the very top of the black layers, at the contact with the overlying white chert. Underlying laminations are undeformed, and there is no evidence of silica infiltration between the two facies, suggesting the texture developed during the early compaction of the topmost carbonaceous laminae while the next layer was deposited on the seafloor. 

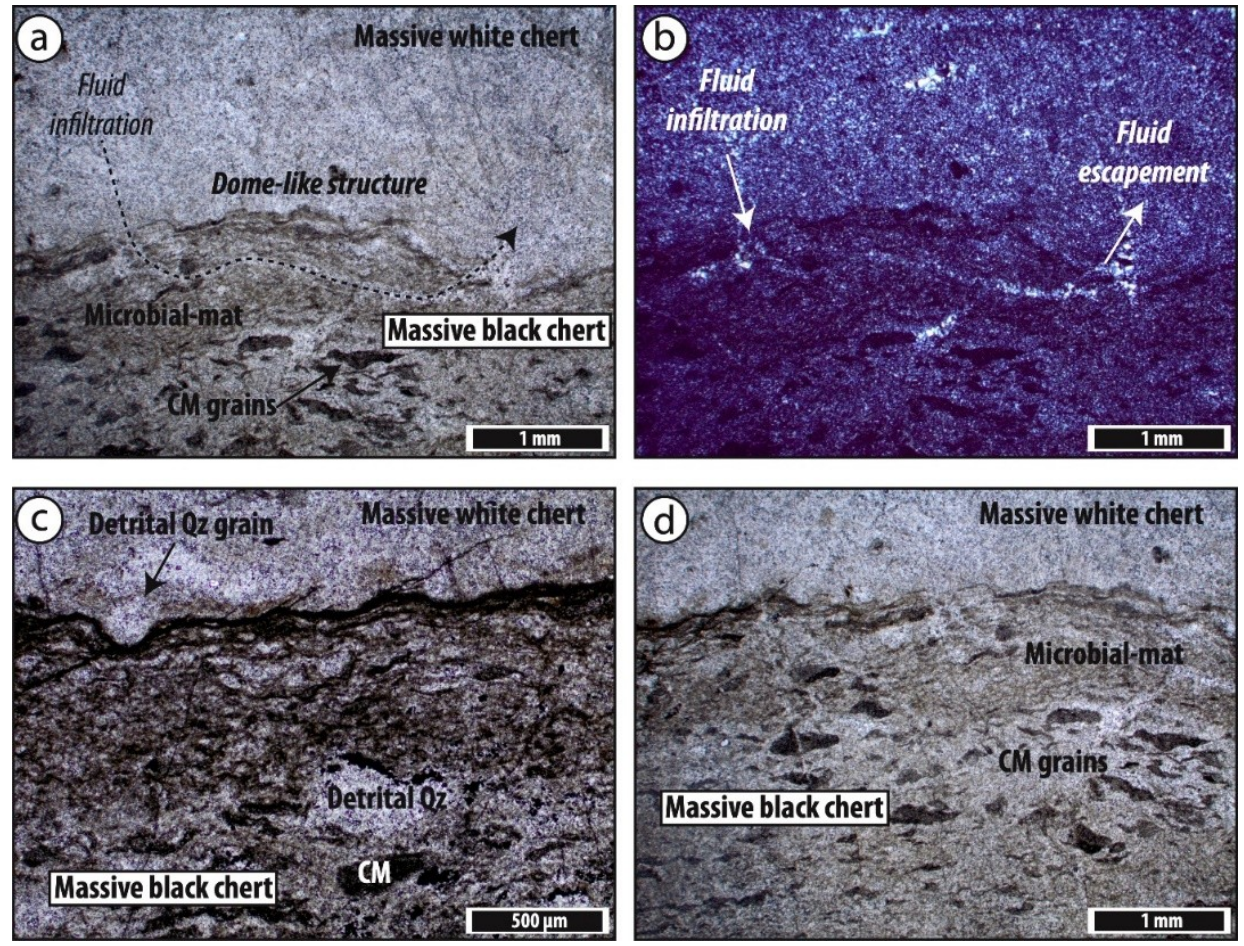

Figure 11. Characteristics of the contact between massive black and white chert layers. (a) Microbial mat-like textures follow the contact and are locally cut by thin, interconnected microquartz veins. The dome structure likely formed early, by density-induced, soft-deformation of the contact. (b,c,d) Sharp and irregular contacts characterized by densely packed zones of carbonaceous matter. $(\mathrm{CM}=$ Carbonaceous matter, $\mathrm{Qz}=$ quartz).

On average, non-compacted microbial mats are continuous laterally for the dimensions of thin sections (Figure 11b) but local disruptions may be observed in the uppermost laminations. In Figure 11a, fine fractures penetrate perpendicularly to the bedding; thin veins, then filled by microquartz $(<20$ $\mu \mathrm{m})$, are connected with each other by lateral branching along the mats. This networking, although observed in two dimensions, resembles desiccation cracks or fluid infiltration structures that may have formed during the deposition of white chert onto living microbial communities.

\section{Chemical Compositions}

\subsection{Analytical Techniques}

Geochemical analyses were performed at ISTerre, Grenoble using a Perkin Elmer Optima 3000 DV ICP-AES for major elements, and an Agilent 7500ce ICP-MS for trace elements. The sample preparation procedure, detailed in the Supplementary Materials, is from Chauvel et al. [39]. Samples were digested in bombs to ensure the complete dissolution of possible resistant minerals. The international rock reference material BHVO-2 was used for calibration, and standards AGV1, BIR1 and DTS2 were run as unknowns (Table 1). The accuracy and precision of the data, evaluated using these analyses, were found to be within $5 \%$ and $<0.6 \%$ of the accepted values for major and trace elements respectively. Uncertainty on the measurements $(1 \sigma)$ varied from $0.01 \%$ to $1.35 \%$ for major elements, and was better than $5 \%$ for trace elements (except for $\mathrm{Zn}$, Mo and Cd, with uncertainties up to $10 \%$ ), showing the very good reproducibility of our data despite extremely low concentrations. Representative analyses of black and white cherts are listed in Table 2 and full data are available in the Supplementary Materials. During trace element analyses, anomalously high Sm contents were measured in some white chert samples. This is interpreted as an artefact from contamination with an Sm of unknown origin. The procedure adopted to evaluate and correct the anomaly is discussed in the Supplementary Materials. 
Table 1. Major and trace elements of standards.

\begin{tabular}{|c|c|c|c|c|c|c|c|c|c|c|}
\hline & $\begin{array}{c}\text { BHVO-1 Values } \\
\text { Used to Calibrate } \\
\text { the Signal }\end{array}$ & $\begin{array}{c}\text { Average } \\
\text { BIR }(n=2)\end{array}$ & BIR Réf & $\begin{array}{l}\text { Reproduc- } \\
\text { Ibility (\%) }\end{array}$ & $\begin{array}{c}\text { Accuracy } \\
(\%)\end{array}$ & AGV1 & AGV-1 Réf & $\begin{array}{c}\text { Accuracy } \\
(\%)\end{array}$ & $\begin{array}{c}\text { Average } \\
\text { DTS-2 } \\
(\mathrm{n}=4)\end{array}$ & $\begin{array}{l}\text { Reproduc- } \\
\text { ibility (\%) }\end{array}$ \\
\hline$(w t \%)$ & $(w t \%)$ & & & & & & & & & \\
\hline $\mathrm{SiO}_{2}$ & 49.9 & & & & & & & & & \\
\hline $\mathrm{TiO}_{2}$ & 2.73 & & & & & & & & & \\
\hline $\mathrm{Al}_{2} \mathrm{O}_{3}$ & 13.5 & & & & & & & & & \\
\hline $\mathrm{Fe}_{2} \mathrm{O}_{3} \mathrm{t}$ & 12.3 & & & & & & & & & \\
\hline $\mathrm{MnO}$ & 0.17 & & & & & & & & & \\
\hline $\mathrm{MgO}$ & 7.23 & & & & & & & & & \\
\hline $\mathrm{CaO}$ & 11.4 & & & & & & & & & \\
\hline $\mathrm{Na}_{2} \mathrm{O}$ & 2.22 & & & & & & & & & \\
\hline $\mathrm{K}_{2} \mathrm{O}$ & 0.52 & & & & & & & & & \\
\hline \multicolumn{11}{|l|}{ LOI } \\
\hline $\begin{array}{c}\text { Sum } \\
(\mathrm{ppm})\end{array}$ & \multicolumn{10}{|c|}{ (ppm) } \\
\hline $\mathrm{Ti}$ & 16300 & 5709.5 & 5630 & 2 & 3 & 6221 & 6080 & 2 & 41.8 & 2 \\
\hline Cs & 0.1 & & 0.00543 & & & 1.35 & 1.29 & 5 & & \\
\hline $\mathbf{R b}$ & 9.11 & 0.179 & 0.239 & 2 & -24 & 70.9 & 66.8 & 6 & 0.04925 & 27 \\
\hline Ba & 131 & 6.03 & 6.47 & 2 & -6 & 1253 & 1230 & 2 & 11.7 & 2 \\
\hline $\mathrm{Li}$ & 4.8 & 3.6 & 3.37 & 2 & 8 & 10.7 & 10.9 & -2 & 2.025 & 2 \\
\hline $\mathrm{Pb}$ & 1.54 & 2.875 & 3.01 & 2 & -3 & 39.9 & 35.9 & 11 & 3.795 & 1 \\
\hline $\mathrm{Sr}$ & 396 & 109.5 & 106 & 2 & 5 & 695 & 657 & 6 & 0.4225 & 1 \\
\hline Th & 1.22 & 0.02745 & 0.0299 & 2 & -7 & 6.33 & 6.35 & 0 & 0.00375 & \\
\hline $\mathrm{U}$ & 0.403 & 0.00898 & 0.00981 & 2 & -7 & 1.86 & 1.83 & 2 & 0.00181 & 5 \\
\hline $\mathrm{Nb}$ & 18.1 & 0.5275 & 0.521 & 2 & 3 & 14.4 & 13.9 & 4 & 0.01468 & 4 \\
\hline Ta & 1.14 & 0.0373 & 0.0384 & 2 & -2 & 0.85 & 0.825 & 3 & & \\
\hline $\mathrm{Zr}$ & 172 & 13.5 & 13.8 & 2 & -1 & 237 & 237 & 0 & & \\
\hline Hf & 4.36 & 0.5795 & 0.574 & 2 & 2 & 5.06 & 5.05 & 0 & & \\
\hline Sc & 32 & 43.4 & 42.4 & 2 & 4 & 12.7 & 12.8 & -1 & 2.64 & 1 \\
\hline V & 317 & 324.5 & 319 & 2 & 3 & 121 & 117 & 3 & 18.8 & 1 \\
\hline $\mathrm{Cr}$ & 280 & 384 & 368 & 2 & 6 & 7.54 & 8.05 & -6 & 12283 & 1 \\
\hline Co & 45.0 & 53.2 & 51.1 & 2 & 5 & 15.9 & 15.3 & 4 & 104 & 2 \\
\hline $\mathrm{Ni}$ & 119 & 172.5 & 165 & 2 & 6 & 14.9 & 14.5 & 3 & 2646 & 2 \\
\hline $\mathrm{Cu}$ & 127 & 120.5 & 115 & 2 & 6 & 58 & 57.2 & 1 & 1.535 & 15 \\
\hline$\underset{(\mathrm{ppt})}{\mathrm{Zn}}$ & $\begin{array}{c}103 \\
(\mathbf{p p m})\end{array}$ & 68.5 & 68.4 & 2 & 1 & 95.9 & 91.7 & 5 & 39.2 & 2 \\
\hline La & 15.2 & 0.606 & 0.598 & 2 & 3 & 38.1 & 38 & 0 & 0.0127 & 8 \\
\hline $\mathrm{Ce}$ & 37.5 & 1.835 & 1.87 & 2 & -1 & 70.3 & 69 & 2 & 0.02363 & 8 \\
\hline
\end{tabular}


Table 1. Cont

\begin{tabular}{|c|c|c|c|c|c|c|c|c|c|c|}
\hline & $\begin{array}{c}\text { BHVO-1 Values } \\
\text { Used to Calibrate } \\
\text { the Signal }\end{array}$ & $\begin{array}{c}\text { Average } \\
\text { BIR }(n=2)\end{array}$ & BIR Réf & $\begin{array}{l}\text { Reproduc- } \\
\text { Ibility (\%) }\end{array}$ & $\begin{array}{c}\text { Accuracy } \\
(\%)\end{array}$ & AGV1 & AGV-1 Réf & $\begin{array}{c}\text { Accuracy } \\
(\%)\end{array}$ & $\begin{array}{l}\text { Average } \\
\text { DTS-2 } \\
(\mathrm{n}=4)\end{array}$ & $\begin{array}{l}\text { Reproduc- } \\
\text { ibility (\%) }\end{array}$ \\
\hline $\operatorname{Pr}$ & 5.35 & 0.375 & 0.374 & 2 & 2 & 8.52 & 8.47 & 1 & 0.00303 & 21 \\
\hline Nd & 24.5 & 2.355 & 2.36 & 2 & 1 & 32.3 & 31.8 & 2 & 0.01283 & 8 \\
\hline Sm & 6.07 & 1.075 & 1.1 & 2 & -1 & 5.85 & 5.77 & 1 & 0.0035 & 14 \\
\hline Eu & 2.07 & 0.516 & 0.523 & 2 & 0 & 1.63 & 1.61 & 1 & 0.0011 & 39 \\
\hline Gd & 6.24 & 1.835 & 1.83 & 2 & 2 & 4.78 & 4.69 & 2 & 0.00503 & 7 \\
\hline $\mathrm{Tb}$ & 0.92 & 0.358 & 0.355 & 2 & 2 & 0.639 & 0.632 & 1 & 0.00065 & 15 \\
\hline Dy & 5.31 & 2.515 & 2.56 & 2 & 0 & 3.64 & 3.55 & 3 & 0.00487 & 7 \\
\hline Ho & 0.98 & 0.567 & 0.571 & 2 & 1 & 0.682 & 0.675 & 1 & 0.001305 & 7 \\
\hline $\mathrm{Y}$ & 26 & 15.4 & 15.1 & 2 & 3 & 20.1 & 19.5 & 3 & 0.0292 & 4 \\
\hline Er & 2.54 & 1.695 & 1.72 & 2 & 0 & 1.88 & 1.84 & 2 & 0.005303 & 6 \\
\hline $\mathrm{Yb}$ & 2 & 1.66 & 1.65 & 2 & 2 & 1.7 & 1.65 & 3 & 0.010375 & 2 \\
\hline Lu & 0.274 & 0.2445 & 0.244 & 2 & 2 & 0.244 & 0.241 & 1 & 0.002255 & 3 \\
\hline
\end{tabular}


Table 2. Representative analyses of major and trace elements.

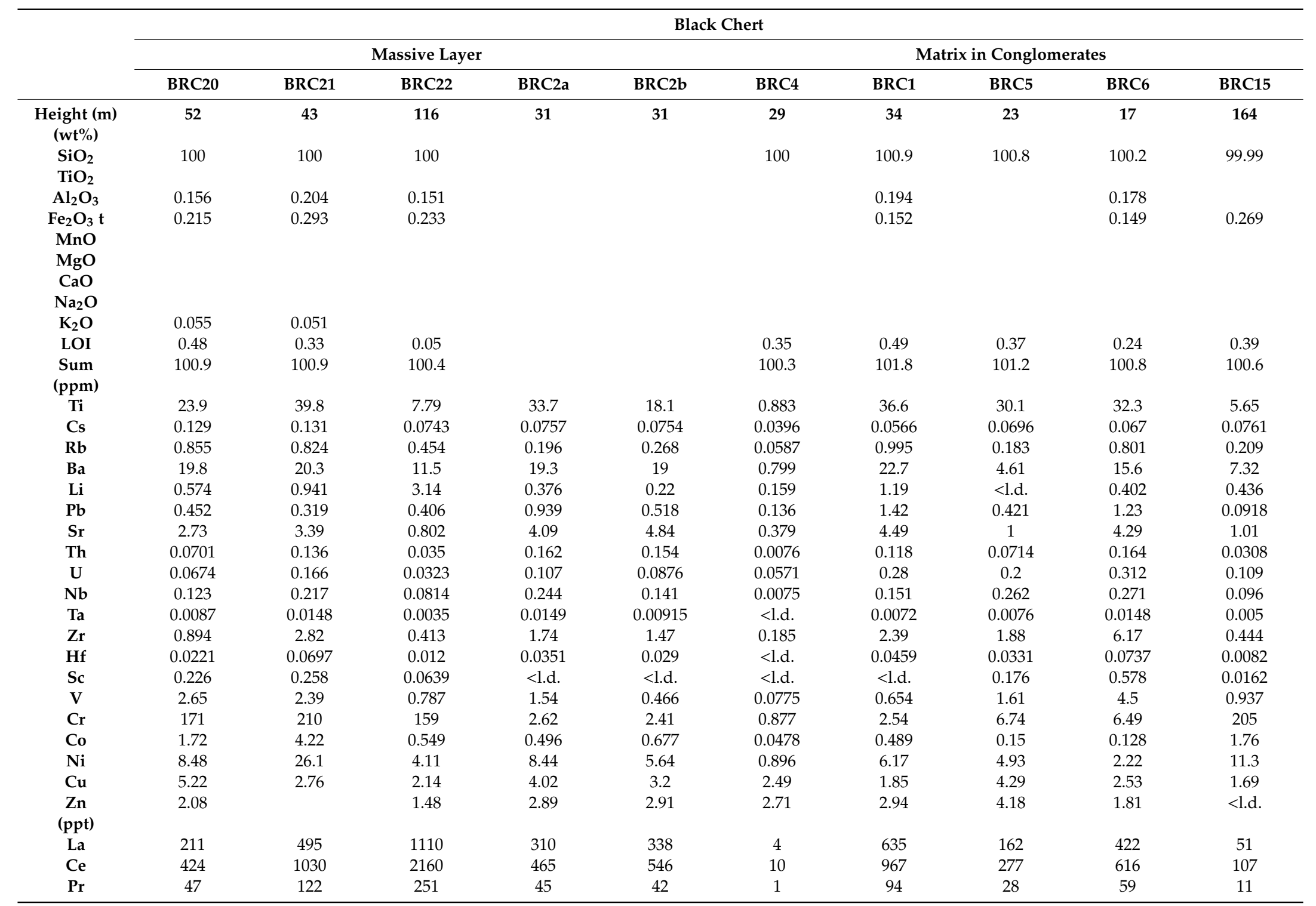


Table 2. Cont

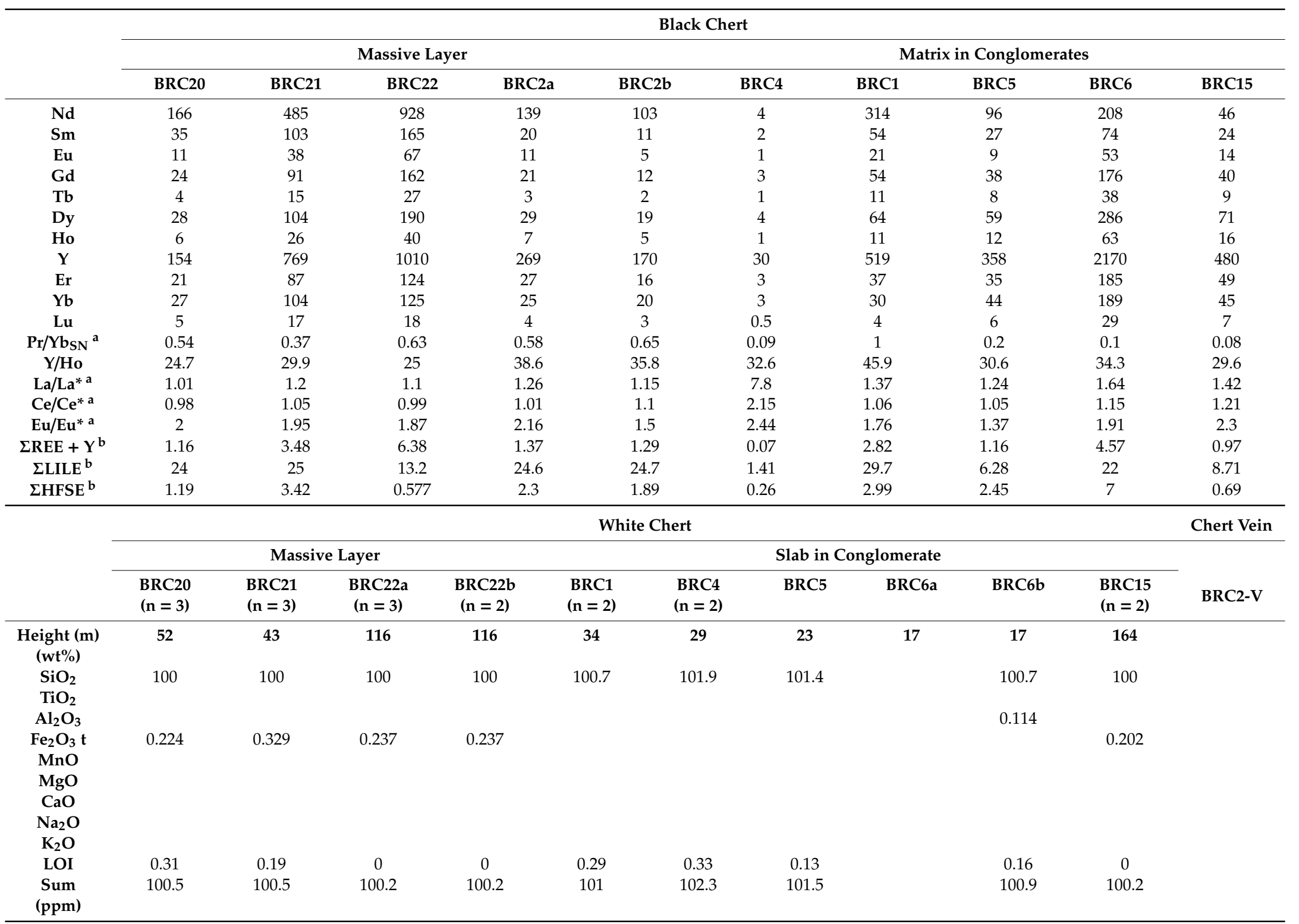


Table 2. Cont

\begin{tabular}{|c|c|c|c|c|c|c|c|c|c|c|c|}
\hline & \multicolumn{10}{|c|}{ White Chert } & \multirow{3}{*}{$\begin{array}{l}\text { Chert Vein } \\
\text { BRC2-V }\end{array}$} \\
\hline & \multicolumn{4}{|c|}{ Massive Layer } & \multicolumn{6}{|c|}{ Slab in Conglomerate } & \\
\hline & $\begin{array}{l}\text { BRC20 } \\
(\mathrm{n}=3)\end{array}$ & $\begin{array}{l}\text { BRC21 } \\
(\mathrm{n}=3)\end{array}$ & $\begin{array}{c}\text { BRC22a } \\
(\mathrm{n}=3)\end{array}$ & $\begin{array}{c}\text { BRC22b } \\
(n=2)\end{array}$ & $\begin{array}{c}\text { BRC1 } \\
(n=2)\end{array}$ & $\begin{array}{l}\text { BRC4 } \\
(n=2)\end{array}$ & BRC5 & BRC6a & BRC6b & $\begin{array}{l}\text { BRC15 } \\
(\mathrm{n}=2)\end{array}$ & \\
\hline $\mathbf{T i}$ & 2.11 & 3.57 & 2.66 & 1.36 & 1.98 & 0.86 & $<$ l.d. & $<$ l.d. & 6.97 & 0.811 & 347 \\
\hline Cs & 0.0589 & 0.0602 & 0.0538 & 0.0408 & 0.0199 & 0.0274 & 0.0285 & 0.0358 & 0.0636 & 0.0377 & 0.359 \\
\hline $\mathbf{R b}$ & 0.386 & 0.48 & 0.266 & 0.198 & 0.163 & 0.0664 & 0.233 & 0.324 & 0.416 & 0.12 & 12.4 \\
\hline $\mathbf{B a}$ & 9.8 & 14.5 & 11.2 & 7.51 & 5.09 & 1.74 & 3.76 & 10.8 & 13.9 & 3.47 & 1856 \\
\hline $\mathbf{L i}$ & 0.3497 & 0.3497 & 0.381 & 0.3 & 0.116 & 0.0845 & $<$ l.d. & 0.183 & 0.237 & 0.257 & 0.72 \\
\hline $\mathrm{Pb}$ & 0.262 & 0.285 & 7.1 & 0.39 & 0.416 & 0.11 & 0.133 & 0.261 & 0.849 & 0.161 & 1.61 \\
\hline Sr & 0.74 & 0.913 & 0.553 & 0.479 & 0.656 & 0.405 & 0.659 & 2.08 & 3.51 & 0.365 & 10 \\
\hline Th & 0.0046 & 0.0103 & 0.0065 & 0.0055 & 0.0099 & 0.0071 & 0.0249 & 0.015 & 0.0497 & 0.002 & 0.721 \\
\hline $\mathrm{U}$ & 0.0081 & 0.0182 & 0.0081 & 0.0093 & 0.0233 & 0.0416 & 0.0151 & 0.0298 & 0.13 & 0.0101 & 0.253 \\
\hline $\mathrm{Nb}$ & 0.0458 & 0.0565 & 0.0488 & 0.0429 & 0.0089 & 0.0075 & 0.0294 & 0.0246 & 0.0795 & 0.0395 & 1.08 \\
\hline $\mathrm{Ta}$ & 0.0011 & 0.001 & 0.0022 & 0.0017 & 0.0004 & <l.d. & 0.0032 & 0.0013 & 0.0076 & 0.0006 & 0.0565 \\
\hline $\mathrm{Zr}$ & 0.159 & 0.377 & 0.214 & 0.191 & $<$ l.d. & 0.153 & $<$ l.d. & $<$ l.d. & 2.16 & 0.111 & 13.3 \\
\hline $\mathrm{Hf}$ & 0.0032 & 0.0083 & 0.0067 & 0.0027 & <l.d. & $<$ l.d. & $<$ l.d. & $<$ l.d. & 0.0216 & $<$ l.d. & 0.284 \\
\hline Sc & 0.0453 & 0.0944 & 0.0467 & 0.0337 & <l.d. & <l.d. & $<$ l.d. & $<$ l.d. & 0.263 & $<$ l.d. & 1.38 \\
\hline $\mathbf{V}$ & 1.14 & 1.46 & 0.788 & 0.845 & 0.0533 & 0.0447 & 0.271 & 0.926 & 1.39 & 0.762 & 13.5 \\
\hline $\mathrm{Cr}$ & 225 & 272 & 172 & 190 & $<$ l.d. & 0.36 & 1.02 & 1.78 & 2.67 & 175 & 77.7 \\
\hline Co & 0.47 & 1.03 & 0.34 & 0.385 & 0.0614 & 0.0249 & 0.0902 & 0.0376 & 0.0438 & 0.397 & 4.15 \\
\hline $\mathrm{Ni}$ & 4.42 & 8.11 & 3.12 & 3.245 & 0.742 & 0.579 & 1.14 & 0.544 & 1.01 & 3.21 & 22.8 \\
\hline $\mathrm{Cu}$ & 1.19 & 1.44 & 0.893 & 2.347 & 3.07 & 0.863 & 1.53 & $<$ l.d. & 2.77 & 0.981 & 17.5 \\
\hline $\begin{array}{c}\mathrm{Zn} \\
(\mathrm{ppt})\end{array}$ & 1.945 & 1.26 & 1.5 & 0.901 & 2.535 & $<$ l.d. & 1.37 & 1.51 & 2.41 & 0.822 & 14.6 \\
\hline La & 19 & 40 & 439 & 50 & 63 & 14 & 138 & 53 & 520 & 7 & 5370 \\
\hline $\mathrm{Ce}$ & 34 & 75 & 297 & 86 & 80 & 26 & 249 & 76 & 692 & 16 & 6080 \\
\hline Pr & 4 & 9 & 46 & 9 & 9 & 3 & 28 & 7 & 70 & 2 & 1120 \\
\hline $\mathrm{Nd}$ & 14 & 33 & 125 & 36 & 29 & 10 & 94 & 27 & 199 & 6 & 3440 \\
\hline $\mathrm{Sm}$ & 30 & 29 & 78 & 54 & 5 & 3 & 23 & 8 & 42 & 22 & 543 \\
\hline Eu & 3 & 5 & 11 & 6 & 2 & 1 & 7 & 4 & 26 & 1 & 129 \\
\hline Gd & 6 & 13 & 29 & 19 & 4 & 3 & 27 & 14 & 56 & 3 & 437 \\
\hline $\mathbf{T b}$ & 2 & 3 & 5 & 4 & 1 & 1 & 3 & 2 & 12 & 1 & 52 \\
\hline Dy & 9 & 20 & 36 & 32 & 4 & 3 & 25 & 18 & 79 & 4 & 298 \\
\hline Ho & 2 & 4 & 8 & 8 & 1 & 1 & 6 & 3 & 18 & 1 & 60 \\
\hline$Y$ & 58 & 152 & 205 & 220 & 28 & 25 & 212 & 147 & 674 & 29 & 2060 \\
\hline Er & 5 & 14 & 24 & 24 & 2 & 2 & 17 & 11 & 59 & 3 & 166 \\
\hline
\end{tabular}


Table 2. Cont.

\begin{tabular}{|c|c|c|c|c|c|c|c|c|c|c|c|}
\hline & \multicolumn{10}{|c|}{ White Chert } & \multirow{3}{*}{$\begin{array}{c}\text { Chert Vein } \\
\text { BRC2-V }\end{array}$} \\
\hline & \multicolumn{4}{|c|}{ Massive Layer } & \multicolumn{6}{|c|}{ Slab in Conglomerate } & \\
\hline & $\begin{array}{l}\text { BRC20 } \\
(\mathrm{n}=3)\end{array}$ & $\begin{array}{l}\text { BRC21 } \\
(\mathrm{n}=3)\end{array}$ & $\begin{array}{c}\text { BRC22a } \\
(\mathrm{n}=3)\end{array}$ & $\begin{array}{c}\text { BRC22b } \\
(n=2)\end{array}$ & $\begin{array}{c}\text { BRC1 } \\
(\mathrm{n}=2)\end{array}$ & $\begin{array}{l}\text { BRC4 } \\
(\mathrm{n}=2)\end{array}$ & BRC5 & BRC6a & BRC6b & $\begin{array}{l}\text { BRC15 } \\
(n=2)\end{array}$ & \\
\hline $\mathbf{Y b}$ & 5 & 15 & 25 & 23 & 2 & 2 & 13 & 10 & 62 & 4 & 159 \\
\hline Lu & 1 & 2 & 4 & 4 & 0.3 & 0.3 & 2 & 2 & 10 & 1 & 25 \\
\hline $\mathrm{Pr} / \mathrm{Yb}_{\mathrm{SN}}{ }^{\mathrm{a}}$ & 0.25 & 0.19 & 0.58 & 0.13 & 1.49 & 0.38 & 0.66 & 0.23 & 0.35 & 0.13 & 2.22 \\
\hline Y/Ho & 31.3 & 34.2 & 26.3 & 29.1 & 35 & 34.4 & 33.4 & 43.4 & 36.6 & 31.1 & 34.1 \\
\hline $\mathrm{La} / \mathrm{La}^{* \mathrm{a}}$ & 1.19 & 1.09 & 1.52 & 1.4 & 1.57 & 1.65 & 1 & 1.7 & 1.24 & 1.33 & 0.87 \\
\hline $\mathrm{Ce} / \mathrm{Ce}^{* \mathrm{a}}$ & 1.01 & 0.96 & 0.58 & 1.07 & 0.99 & 1.3 & 0.92 & 1.14 & 0.92 & 1.26 & 0.53 \\
\hline $\mathrm{Eu} / \mathrm{Eu}^{* a}$ & 2.37 & 2.24 & 1.78 & 1.84 & 1.69 & 2.34 & 1.42 & 1.54 & 2.41 & 2.19 & 1.2 \\
\hline$\underset{b}{\Sigma R E E}+Y$ & 0.19 & 0.41 & 1.33 & 0.57 & 0.23 & 0.09 & 0.84 & 0.38 & 2.52 & 0.1 & 19.94 \\
\hline$\Sigma_{\text {LILE }^{b}}$ & 11.2 & 16.2 & 19.2 & 8.62 & 6.34 & 2.35 & 4.81 & 13.5 & 18.74 & 4.15 & 1880 \\
\hline$\Sigma H_{F S E}{ }^{b}$ & 0.22 & 0.47 & 0.29 & 0.25 & 0.04 & 0.21 & 0.07 & 0.07 & 2.45 & 0.16 & 15.7 \\
\hline
\end{tabular}

a Pr/YbSN ratio and La, Ce and Eu anomalies are calculated using concentrations normalized to Post-Archean Australian Shale (Taylor and McLennan, 1985). La/La* $=[\mathrm{La} /(3 \mathrm{Pr}-2 \mathrm{Nd})] \mathrm{SN}$ $\mathrm{Ce} / \mathrm{Ce}^{*}=[\mathrm{Ce} /(2 \mathrm{Pr}-\mathrm{Nd})] \mathrm{SN} ; \mathrm{Eu} / \mathrm{Eu}^{*}=[\mathrm{Eu} /(2 \mathrm{~Gb}-\mathrm{Tb})] \mathrm{SN}$. b Total measured concentrations of rare-earth elements from La to Lu and yttrium $(\Sigma \mathrm{REE}+\mathrm{Y})$, large ion lithophile elements $\mathrm{Cs}, \mathrm{Rb}$, $\mathrm{Ba}, \mathrm{Pb}$ and $\mathrm{Sr}(\Sigma \mathrm{LILE})$, high field strength elements Th, U, Nb, Ta, Zr and Hf ( $\Sigma$ HFSE) (<l.d. = below detection limit). 


\subsection{Results}

Both black and white cherts contain close to $100 \% \mathrm{SiO}_{2}$ with most other major elements below the detection limit (Tables 1 and 2). The black cherts contain low $\mathrm{Al}_{2} \mathrm{O}_{3}(<0.2 \mathrm{wt} \%), \mathrm{TiO}_{2}(<0.01 \mathrm{wt} \%)$ and $\mathrm{K}_{2} \mathrm{O}(<0.07 \mathrm{wt} \%)$ attributed to the carbonaceous matter and/or the rare rounded detrital grains preserved as ghosts in the matrix. In the upper units, both chert types contain low, yet significant iron contents, from 0.15 to $0.33 \mathrm{wt} \%$ (Table 1), probably in the minute disseminated oxides (cf. Section 4).

In Figure 12, the chert compositions are compared to siliceous sediments from the Kromberg type section, which were interpreted by Ledevin et al. [40] as seawater-derived cherts deposited together with a small amount of detrital K-feldspar and clay minerals (now sericite). These cherts lie on mixing curves between pure silica and sericite endmembers, with 5\% to 50\% sericite accounting for both aluminium and titanium contents. The Buck Reef cherts, in contrast, plot close to the pure silica endmember and contain virtually no clay in white cherts, and no more than $1 \%$ in black cherts.
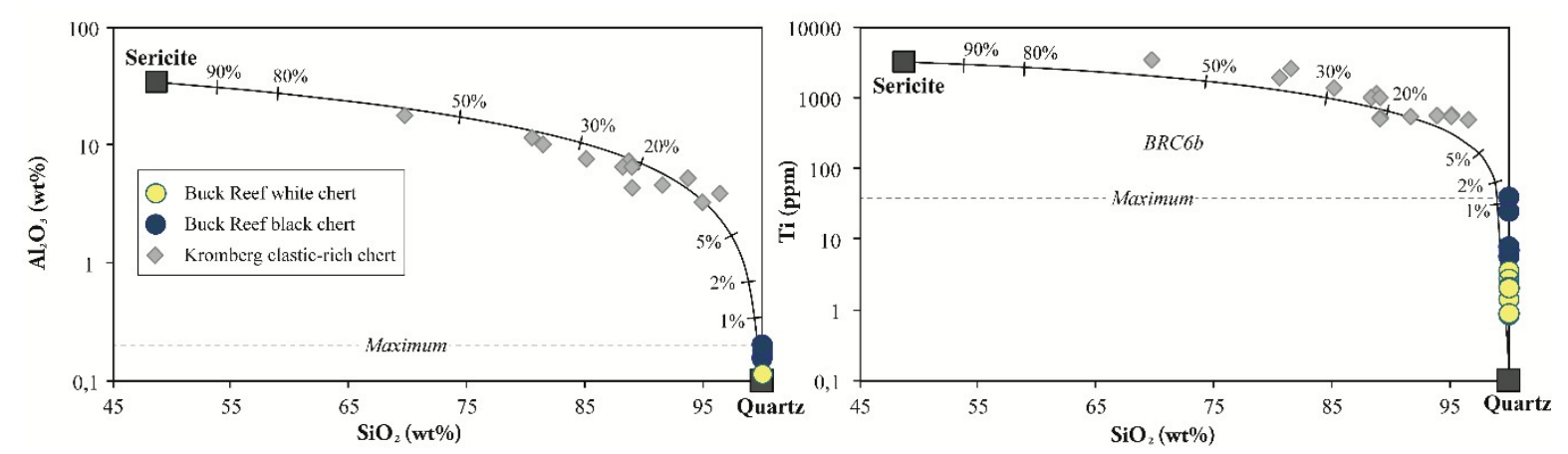

Figure 12. $\mathrm{SiO}_{2}$ versus aluminium and titanium contents for Buck Reef chert samples. Clastic-rich cherts from the Kromberg type section [14] are shown for comparison. Solid lines are mixing curves between quartz and sericite endmembers. Sericite composition is from Ledevin et al. [40]. Sericite represents less than $0.1 \%$ of white cherts and no more than $1 \%$ of the black cherts.

Trace element concentrations are extremely low (Tables 1 and 2), with a total rare earth element $(\mathrm{REE})+\mathrm{Y}$ contents below $1 \mathrm{ppm}(<0.5 \mathrm{ppm}$ on average) in white cherts and up to $6.4 \mathrm{ppm}$ in the black cherts that contain significant $\mathrm{Al}_{2} \mathrm{O}_{3}$ and $\mathrm{K}_{2} \mathrm{O}$ (Figures 12 and 13). Total contents of large ion lithophile elements (LILE) and high-field-strength elements (HFSE) are below $20 \mathrm{ppm}$ and $0.5 \mathrm{ppm}$ respectively in the white cherts, but are two to 13 times greater in the adjacent black layers. One sample of slab conglomerate (BRC6b) is systematically enriched compared to the other white chert samples, in line with the enrichment of $\mathrm{Al}_{2} \mathrm{O}_{3}, \mathrm{~K}_{2} \mathrm{O}$ and the REE in the black matrix of this sample (Table 1). When normalized to Th (Figure 13), certain elements- $\mathrm{Ba}, \mathrm{Rb}, \mathrm{Sr}, \mathrm{Pb}, \mathrm{Co}, \mathrm{Ni}$ and $\mathrm{Cr}$-are enriched in the white chert compared to the adjacent black layer. The degree of enrichment is highly variable between black-white chert couplets, from two to 100. 


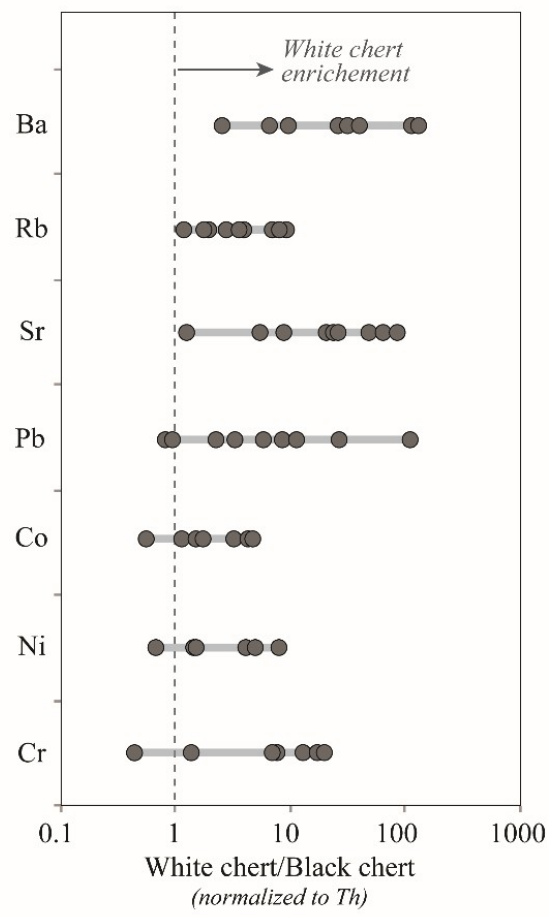

Figure 13. Comparison of black and white chert trace element composition. Elements of the y-axis are normalized to $\mathrm{Th}$. White cherts are significantly enriched in $\mathrm{Ba}, \mathrm{Rb}, \mathrm{Sr}, \mathrm{Pb}$, and to a lesser extent in $\mathrm{Co}$, $\mathrm{Ni}$ and $\mathrm{Cr}$. The degree of enrichment strongly varies from one black-white chert couple to the other.

Interesting patterns emerge from the stratigraphic variations in Figure 14, where we observe a decoupling up-section of the white and black chert characteristics: the black cherts maintain a relatively constant composition while the white cherts become increasingly enriched in $\mathrm{Pb}, \mathrm{Co}, \mathrm{Ni}$ and $\mathrm{Cr}$ relative to incompatible elements, like Ti (Figure 14). Both $\mathrm{Sr} / \mathrm{Ba}$ and $\mathrm{Y} / \mathrm{Ho}$ decrease towards the upper unit (Figure 14).

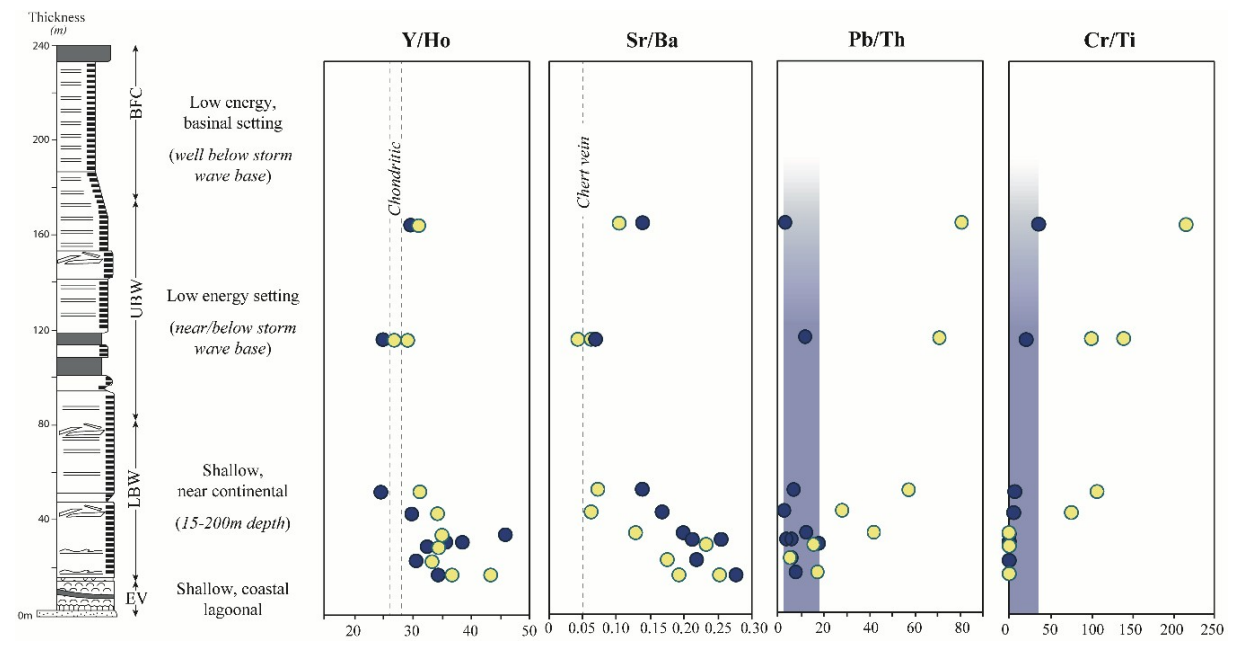

Figure 14. Stratigraphic evolution of some key ratios across the Buck Reef sequence. Stratigraphy on the left is modified from Tice and Lowe [2]. From bottom to top, the results highlight (1) a global decrease of $\mathrm{Y} / \mathrm{Ho}$ towards chondritic values and a decrease of $\mathrm{Sr} / \mathrm{Ba}$ ratio; and (2) a decoupling of white chert composition from black cherts, with significant increases in $\mathrm{Pb}$ and $\mathrm{Cr}$ contents, along with those of $\mathrm{Ni}, \mathrm{Ba}$ and $\mathrm{Co}$ which are not shown. These variations are interpreted as increasing hydrothermal contributions to the ambient chemistry during Buck Reef chert deposition. 
Trace element patterns (normalized to Post-Archean Australian shale [41]) of Buck Reef banded cherts and a vein of white chert (BRC2-V; Table 1) are shown in Figure 15, together with modern seawater, hydrothermal fluids and seawater-derived cherts typical patterns [42-44]. Black cherts, both in massive or conglomerate layers, show large variability: the LREE are either flat or strongly depleted $\left(\mathrm{Pr} / \mathrm{Yb}_{\mathrm{SN}}=0.09-1.00\right) ; \mathrm{La}$ and $\mathrm{Ce}$ anomalies are absent or weakly to strongly positive $\left(\mathrm{La} / \mathrm{La}^{*}=1.0-7.8\right.$; $\mathrm{Ce} / \mathrm{Ce}^{*}=0.98-2.15$; Table 1$)$; the Eu anomaly is strongly positive $\left(\mathrm{Eu} / \mathrm{Eu}^{*}=1.37-2.44\right)$; and $\mathrm{Y} / \mathrm{Ho}$ ranges from subchondritic to superchondritic $(\mathrm{Y} / \mathrm{Ho}=25$ to 46$)$. The presence of variable amounts and types of carbonaceous matter and/or detrital quartz and clay is thought to explain the range of compositions.
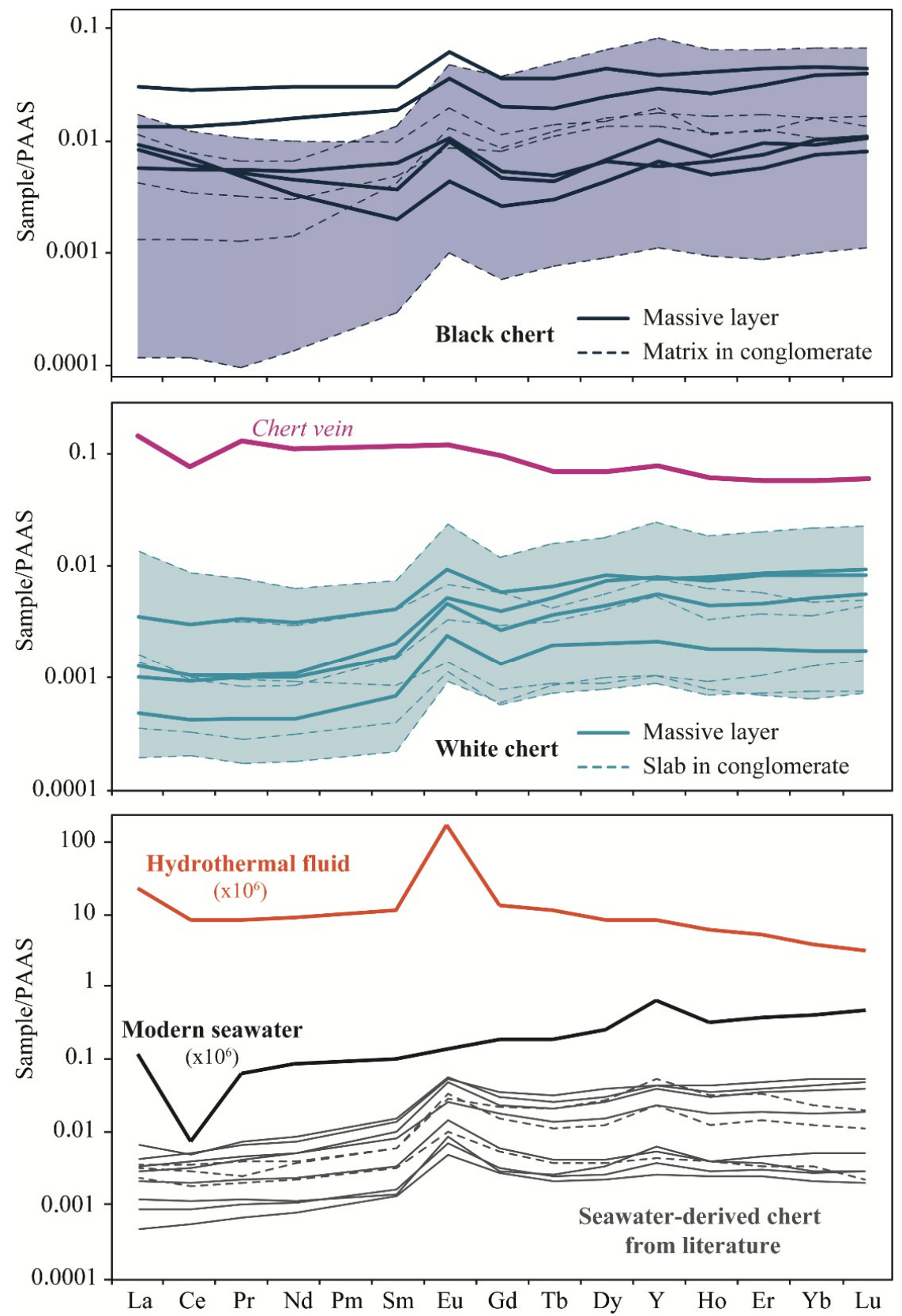

Figure 15. REE $+\mathrm{Y}$ patterns for Buck Reef black and white chert and one chert vein (BRC2-V). All patterns are normalized to Post-Archaean Australian Shale (PAAS) [41]. Samarium in white samples is a corrected value calculated as $\mathrm{Sm}^{*}=\left(2 / 3 \mathrm{Nd}_{\mathrm{SN}}\right)+\left(1 / 3 \mathrm{Gd}_{\mathrm{SN}}\right)$ (see Supplementary Materials for a discussion of the Sm anomaly). The composition of average Pacific seawater [42], Mid-Atlantic Ridge hydrothermal fluids $\left(180-360^{\circ} \mathrm{C}\right.$; [43]) and seawater derived chert from the Pangola BIFs (plain line, [44]), and the Marble Bar units (dotted line, [20]) are shown for comparison. 
White cherts, both in massive layers and chert slabs, are less variable and display highly fractionated REE patterns characterized by strong LREE depletion $\left(\mathrm{Pr} / \mathrm{Yb}_{\mathrm{SN}}=0.13-0.66\right)$ and nearly flat HREEs (Figure 15). One slab (BRC1) is distinguished by LREE enrichment $\left(\mathrm{Pr} / \mathrm{Yb}_{\mathrm{SN}}=1.5\right)$. The $\mathrm{La}$ and $\mathrm{Eu}$ anomalies are weakly to strongly positive, with $\mathrm{La} / \mathrm{La}^{*}$ ranging from 1 to 1.7 and $\mathrm{Eu} / \mathrm{Eu}^{*}$ from 1.42 to 2.41 , and the $\mathrm{Ce}$ anomaly is absent to positive (Ce/Ce* up to 1.3), except for one sample with a negative value of 0.58 . Yttrium is variably enriched, producing chondritic to superchondritic $\mathrm{Y} / \mathrm{Ho}$ ratios from 26 up to 43. The white chert slabs in conglomerates show the highest $\mathrm{Y} / \mathrm{Ho}$ ratio.

The chert vein sample BRC2-V has overall higher REE contents and stronger enrichment in LREE, with a $\operatorname{Pr} / \mathrm{Yb}_{\mathrm{SN}}$ ratio of 2.2. It lacks a La-anomaly $\left(\mathrm{La} / \mathrm{La}^{*}=0.87\right)$ and has a small positive Eu-anomaly $\left(\mathrm{Eu} / \mathrm{Eu}^{*}=1.20\right)$.

\section{Discussion: Origin of the Buck Reef Cherts}

Despite the controversy surrounding the mode of silica precipitation and origin of the banding, cherts are widely used to investigate the environmental conditions prevailing in Archean oceans. A better knowledge of how they form is crucial to any evaluation of the potential of such chemical sediments as paleo-environment recorders.

As mentioned in the introduction, three main hypotheses have been proposed to explain the banding in B\&W cherts: (1) silicification of a finely bedded protolith ([4-6]; (2) diagenetic segregation from a homogeneous silica-carbonaceous mixture [2,7]; or (3) primary deposition of alternating carbonaceous-rich and pure silica sediments [12,24,44].

In the following discussion, field, petrological and geochemical evidence is used to advocate that the cherts are primary chemical sediments. We then propose a model that explains their formation, the origin of the silica and that of the banding.

\subsection{The Banding is Not Inherited from Bedding in a Sedimentary or Volcanic Precursor}

In Archean terrains, metamorphism and Si- and K-metasomatism commonly transform volcanic and volcaniclastic rocks into a mosaic of secondary microquartz and sericite and strongly change the chemistry of the protolith (e.g., [40,45-47]. However, unless disturbed by synchronous or later deformation, petrological and chemical traces of the protolith usually remain in the form of primary structures, pseudomorphs after precursor mineral, remnants of refractory minerals and preservations of metasomatism-resistant elements, such as $\mathrm{Al}$, Ti and the REEs $[14,22,23,48,49]$.

In the Buck Reef cherts, we found abundant evidence for Si-rich fluid circulation in the form of silica veins, cavity-filling textures and the disappearance of primary textures behind pervasive silicification fronts (Sections 3 and 4). However, an absence of relicts of clastic minerals in the black layers (zircon, Ti-oxide, silicates, etc; Section 4.2), the purity of the white layers (Figure 6), and the extremely low concentrations of elements resistant to $\mathrm{Si}-\mathrm{K}$ metasomatism (i.e., $\mathrm{Al}_{2} \mathrm{O}_{3}, \mathrm{Ti}, \mathrm{HFSE}$ ), suggest that the cherts were not produced by silicification of a sedimentary precursor. Additional arguments are the marked contrast in texture and composition of black and white layers, repeated hundreds of times up through the sequence, and the sharp contacts between the layers, which resemble contacts between sedimentary beds and are very different from diffuse contacts between silicification fronts. We find it difficult to accept that silicification could be sufficiently selective that it produced the alternation of almost pure silica layers with adjacent layers that contain significantly higher contents of biogenic organic matter.

An alternative explanation is that the white chert bands are hydrothermal veins, injected lit-par-lit into a sedimentary sequence. This interpretation is negated by the uniform thickness of the white bands, which systematically is similar to that of adjacent black bands, and the concordance of the bands, which never cut across the other strata. In addition, the white bands consist almost entirely of $\mathrm{SiO}_{2}$, without the potassium and other fluid-mobile elements that are present when other types of rock are silicified [49]. 
In their overall form and internal organization, the banded black and white cherts resemble banded iron formations, which most authorities interpret as finely bedded sedimentary rocks ([47] and references therein).

\subsection{The Banding is Not Diagenetic.}

Tice and Lowe [2] and Lowe and Fisher Worrell [7], proposed a diagenetic origin for the banding, also advocated for banded iron formations (e.g., [50-52]) and younger bedded chert-shale sequences [53,54]. These authors argued that during the diagenesis of a mixture of chemical sediment, detrital particles and organic matter on the seafloor-the silica segregated to form the white chert bands, the rest forming the black chert layers. Lowe [34] advanced two key arguments in favour of the model: (a) the thickness of the white bands varies little across the outcrop, both in space and time, which they consider to be inconsistent with primary deposition; and (b) if white cherts were rapidly deposited sediments, they would have mixed to some extent with carbonaceous matter. The following arguments call into question these interpretations:

(1) Sediment-like contacts. As described in Sections 3 and 4.4, contacts between black and white chert layers are sharp and frequently marked by large- and small-scale soft deformation structures typical of seafloor sedimentation. In some places, detritus-rich black chert fills troughs with typical fan structures in underlying white chert. With the exception of local and thin quartz veins, and silicification fronts of limited extent, there is no evidence for fluid migration between the two facies. Finally, we interpret the densely packed laminae at the top of some black layers as early compaction features, developed as the following white chert layer was deposited on the seafloor.

(2) Slab conglomerates. From their structure, texture and mineralogy, it is evident that the slabs are the disrupted equivalent of massive white chert layers. The angular to sub-angular shapes of the slabs indicate that the white layers were first deposited, then became indurated, at most a few tens of centimetres from the sediment-water interface.

(3) Preservation of microbial mats in black cherts. The micro-scale carbonaceous laminations $(<15 \mu \mathrm{m}$-thick) in black cherts are interpreted as remnants of microbial mats. The sharpness of contacts with surrounding white cherts, the lack of abundant silica diffusion features and the lateral continuity and preservation of such delicate biogenic structures, are inconsistent with the diagenetic segregation hypothesis.

(4) Evidence for "granule-like" sedimentation. Stefurak et al. [24,44], observed silica granules in Buck Reef cherts and proposed that they are primary silica deposits from ambient seawater, further challenging the diagenesis hypothesis.

\subsection{Limitations of the Hydrothermal Plume Model}

From the above discussion, we conclude that the black and white cherts formed at the seafloor, by the deposition of almost pure, orthochemical silica, periodically accompanied by organic and detrital components. The process was cyclic and repetitive; it prevailed over a large area consistent with the spatial extension of the Buck Reef, and it persisted over a long period of time that coincided with increasing depth of deposition.

Geilert et al. [12] invoked mixing of hydrothermal plumes and water mass in a stratified ocean, a popular model for banded iron formations [8-10], to explain the banding in the Buck Reef. In this model, the black bands formed during enhanced hydrothermal activity, when a hydrothermal plume passed above the chemocline, mixed with surface waters and incorporated organic matter that was concentrated in the euphotic zone. The dissolved metals within the plume reacted with any available oxygen and served as nuclei for silica precipitation. During periods of low hydrothermal activity, the plume mixed and interacted with bottom waters: most of the metals remained dissolved under reducing conditions while low temperatures reduced silica solubility and promoted pure silica precipitation. Geilert et al. [12] noted that the silicon isotope ratio of the black layers resembled that of hydrothermal fluids. 
We question this model not because we doubt a hydrothermal origin of many of the components of $B \& W$ cherts but because we do not understand how the flux of hydrothermal fluid could be regulated in the regular and repetitive manner needed to explain the banding. More specifically:

(1) Variation in the intensity of hydrothermal activity cannot explain the remarkably uniformity of the black and white chert bands. Hydrothermal activity at modern ocean ridges or other sites of submarine volcanism occurs at multiple sites, all of which operate sporadically. There is little reason to suspect that Archean systems, which operated when magma fluxes were higher and oceanic crust or plateaus more widely dispersed, would have functioned differently. On this basis we believe the combined hydrothermal flux from these sites, the inferred shallow lagoonal setting of the lower part of the Buck Reef sequence, was unlikely to be switched on and off in a regular and repeated manner.

(2) It is not evident how mixtures of hydrothermal fluids in cold bottom seawater would be transported into shallow-water depositional settings at the margins of continents. Upwelling of bottom seawater might occur sporadically, but unless controlled by external forcing, is unlikely to be repeated regularly and repeatedly. Geochemical modelling (e.g., [55]) indicates that at $3.5 \mathrm{Ga}$, only $20-50 \%$ of the mass of modern continental crust had formed, and because ocean volumes were greater at this time $[55,56]$, most of these continents were submerged. Consequently, today's large, north-south aligned continents that regulate modern ocean circulation probably did not exist. It is difficult to model the circulation of ocean currents and the upwelling of deep ocean waters around the small, probably isolated, land masses that constituted the Archean continents, but there is little to suggest that upwelling at the margin of nascent South Africa would have fluctuated in a regularly repeated manner (see also the discussion in Section 6.4.3).

(3) The involvement of a hydrothermal plume is inconsistent with the very low concentrations of iron and other metals in the Buck Reef cherts. We recognize that the plume might have lost most of its metals as it precipitated Fe oxides following interaction with oxidizing surface waters. However, it is unlikely in this case that the plume retained enough silica to generate massive cherts.

Positive europium anomalies are common features in Archean sediments from a variety of depositional settings, which suggests global Eu-enrichment of Archean seawater due to enhanced hydrothermal inputs at that time ([1,57-60]. Throughout the Buck Reef stratigraphy, the positive Eu-anomaly is relatively constant and strongly positive (Eu/Eu* from 1.37 to 2.41 ), which we attribute to the wide scale Eu-enrichment of Archean oceans. We rule out a local high-T hydrothermal origin due to the lack of obvious plumbing structures (i.e., vent mounds, chimney or dikes), and the lack of an identifiable heat source [2].

\subsection{A New Model for the Buck Reef Chert}

Based on field, petrological and geochemical evidence, we developed a model that explains the source of the silica, the origin of the two types of cherts and the cause of the banding. We considered two types of banding: macro-banding ( 5 to $20 \mathrm{~cm}$ thick) that persists through the entire unit, and micro-banding (5-15 $\mu \mathrm{m}$ thick) that is restricted to the black bands, especially in the lower unit.

\subsubsection{Origin of the Silica: Shallow Marine, Low Temperature Hydrothermalism}

Tice and Lowe [2] Lowe and Fisher Worrell [7] considered the Buck Reef setting to have been free of active hydrothermalism, based on the absence of active heat sources at the time it formed, and the lack of venting structures, spring mounds and tufas in the area. De Vries et al. [5] disputed this conclusion on the basis that they had identified hydrothermal breccias and possible sinter deposits within the base of the sequence. Instead, they attributed the breccia pods and layers to locally explosive hydrothermal activity that alternated with low-energy sedimentation.

In this study, we found evidence of circulation of Si-rich fluids, such as the silicification fronts, the abundant silica veins cutting through the cherts and the occurrence of void-filling textures within conglomeratic layers (Section 4). The preservation of fibrous quartz (Section 4), the lack of oxygen 
isotope resetting across the sequence (e.g., [61]) and microthermometric analyses on fluid inclusions (e.g., [62]) indicate relatively low temperatures for the fluids, probably below $150{ }^{\circ} \mathrm{C}$.

The massive white chert layers, with their almost pure silica mineralogy and spectacularly low concentrations of all elements other than $\mathrm{SiO}_{2}$ (Figures 12 and 15), provide the best opportunity to estimate the chemical signature of pure silica component, and therefore, investigate the presence of possible hydrothermal contribution to the local basin chemistry. In both massive layers and chert slabs, the REE + Y composition shares some characteristics with modern seawater and seawater-derived silica precipitates [57,63] (Figure 15; namely, strong depletion of the LREE and more moderate enrichment of $\mathrm{La}, \mathrm{Y}$ and $\mathrm{Sr}$. However, the positive Eu-anomaly and enrichment in key elements, such as $\mathrm{Ba}, \mathrm{Pb}( \pm$ $\mathrm{Rb}), \mathrm{Co}$ and $\mathrm{Ni}$, confirm additional contributions from fluids that had interacted with the Archean oceanic crust. The barium enrichment, in particular, is diagnostic of low temperature hydrothermal inputs, as observed in other hydrothermally altered, Si- and Ba-rich greenstones from Barberton $[64,65]$ or Pilbara [66]. Moreover, the lack of barite deposits, despite the Ba enrichment, suggests the basin was poor in sulfate, and therefore, most likely unaffected by fluid contributions from any magmatic intrusion. Instead, the lack of significant $\mathrm{Fe}, \mathrm{Zn}, \mathrm{Mn}$ and $\mathrm{Cu}$, and absence of Fe-rich and S-rich deposits in most of the Buck Reef sequence is more consistent with low temperature fluids, close in composition to modern white smokers or continental epithermal fluids (e.g., [67-69]).

The Buck Reef cherts were deposited on a kilometre-thick sequence of felsic volcanics, fluvial conglomerates, sandstones and diamictites [70], all strongly silicified [47]. The notable absence of iron in the cherts requires that fluid circulation did not reach the mafic-ultramafic rocks that lie at least $1 \mathrm{~km}$ beneath the felsic units and that the fluids interacted only with the felsic volcanics and fluvial sedimentary rocks. Fluid-rock interaction, devitrification of volcanic glasses and alteration of feldspars to clay minerals in these felsic lithologies would release acidic fluids highly enriched in silica, and $\mathrm{Eu}, \mathrm{Ba}, \mathrm{Pb}, \mathrm{Sr}$ and $\mathrm{Rb}$ [71], thus explaining their enrichment in the surface sediments. Similar low-temperature, shallow convection cells were also inferred from other parts of the Barberton belt $[47,72]$ and from the Pilbara craton $[20,73]$.

Tice and Lowe [2] Lowe and Fisher Worrell [7] considered the Buck Reef area as a shallow, near-continental platform that progressively subsided and eventually connected to the open ocean. On the other hand, Grosch et al. [74] argued that the basin was more likely an epeiric sea partially or fully isolated from the open ocean. In such a restricted setting, local and diffuse low-temperature fluid discharges from the seafloor may have played an important role in controlling the composition of local seawater, as is typical of areas remote from oceanic ridges and back-arc settings.

From the above discussion, we conclude that the Buck Reef resembles a modern near-continental epithermal system, where local seawater was nourished by pervasive, low temperature hydrothermal discharges issuing from intense fluid-rock interaction in the sub-seafloor. Continental weathering and riverine inputs may constitute an additional, although minor source of silica [75-79]. Mixing of warm, acidic, Si-rich fluids from the seafloor with colder, more alkaline, Si-rich seawater triggered continuous precipitation of abundant silica, leading to deposition of the cherts.

Upwards through the stratigraphy; the concomitant decrease in $\mathrm{Sr} / \mathrm{Ba}$ ratio; the slight shift from superchondritic to chondritic $\mathrm{Y} / \mathrm{Ho}$ ratio; and the increasing $\mathrm{Ba}, \mathrm{Pb}, \mathrm{Co}$ and $\mathrm{Cr}$ contents (Figure 14), are all features we tentatively attribute to increasing contributions from hydrothermal fluids at the expense of the oceanic signal [80,81]. Geilert et al., [12] also reported a shift from positive $(+0.33 \%$ o) to negative $(-1.27 \%$ o $){ }^{30} \mathrm{Si}$ values in the white layers from the base to the top of the Buck Reef, which is consistent with increasing involvement of silica that interacted with the oceanic crust.

The successive lithologies recorded a progressive deepening of the basin [2], from evaporitic conditions (i.e., braided sandstone with nahcolite pseudomorphs); to medium-energy conditions (i.e., detritus-rich, $\mathrm{B} \& \mathrm{~W}$ chert, slab conglomerates); and then a deep, quiet environment, far from coastal turbulence (i.e., finely laminated B\&W cherts). Greater depth resulted in a decrease of wave activity and coastal turbulences, which would have affected the extent of seawater and hydrothermal fluid mixing at the surface: efficient mixing under shallow, high-energy conditions would dilute the 
hydrothermal signal, whereas quiet conditions would promote hydrothermal fluid concentrations and more pronounced contribution to the deep-sea deposited cherts. Alternatively, as the basin depth increased, chemically distinct water masses became involved: the depth might have passed below a chemocline that separated surface water from more hydrothermally-influenced bottom seawater, or the basin might have progressively connected to the open ocean, itself more widely controlled by widespread, high temperature hydrothermalism. Eventually, mixing of iron-rich, Si-poor bottom waters and/or open ocean waters with ambient marine fluids led to the precipitation of the iron-rich cherts at the top of the unit.

\subsubsection{The Origins of the Fine Layering: Seasonal Variations Recorded within the Black Layers}

Mixing of hydrothermal fluids with seawater might have triggered continuous precipitation of abundant silica but does not explain the origin of the banding itself. Tidal and solar cycles, or annual seasonal cycles, have been proposed to explain rhythmic banding in banded iron formations [82,83], but the time scales of these cycles are probably too short to explain the $\mathrm{cm}$ - to dm-thick alternation of black and white layers in the Buck Reef. If we assume a thickness of $400 \mathrm{~m}$ for the entire sequence, an average thickness of $5 \mathrm{~cm}$ for each band and suppose that a black-white couplet represents an annual cycle, then the whole sequence would have been deposited in about 4000 years. The corresponding sedimentation rate would be $5 \mathrm{~cm} / \mathrm{yr}$, which is higher than the 0.03 to $1 \mathrm{~mm} / \mathrm{yr}$ proposed for Precambrian BIF [84-87], far greater than the average $0.01-0.04 \mathrm{~mm} / \mathrm{yr}$ accumulation rate of modern, biogenic siliceous ooze (e.g., [88]) and many orders of magnitude greater than the accumulation rate of red clays and other deep-sea sediments.

However, annual or seasonal variations may explain the far finer micro-layering within individual black chert layers from the lower part of the sequence. As described in Section 4.2, carbonaceous laminations of microbial mats are intercalated with thin silica bands, each of which is 10-15 $\mu \mathrm{m}$-thick in average (Section 4.2, Figures 8 and 11). Konhauser et al. [86] interpreted similar structures in modern siliceous sinters from Iceland as seasonal microbial deposits, with active growth during summer onto a silica-rich substratum, followed by quiescence during winter when abiological silica precipitation exceeds the bacteria growth capacity. We estimate that that one black layer (on average 5 $\mathrm{cm}$-thick) contains between 1600 and 2500 black-white couplets, and if these are annual cycles, the sedimentation rate would be $0.02-0.03 \mathrm{~mm} / \mathrm{yr}$, which is very similar to the estimates for modern or ancient siliceous ooze.

Although such calculations are subject to major uncertainties, the orders of magnitude are probably correct. Therefore, we suggest that the massive black layers represent "normal" sedimentation in the Buck Reef basin: each black band formed within a few thousand years, by annual cycles of silica precipitation and microbial growth similar to those reported by Konhauser et al. [89]. The silica mostly came from the diffuse hydrothermal circulation (Section 6.4.1) with a possible minor contribution from river waters. The silica content probably was close to saturation in the water column, while carbonaceous matter was produced by organisms confined to the upper euphotic zone [2]. Detrital carbonaceous grains could have served as nuclei that aided silica precipitation, as suggested by the silica coatings commonly observed around detrital carbonaceous grains (Section 4.2; Figure 9b). In the water column, the carbonaceous and siliceous snow would settle as ooze on the seafloor, where it served as substrate for the microbial colonies.

The presence of the warm, nutrient-rich emanations from the seafloor, the possible contribution from continental weathering (e.g., phosphorus; [90]) and the initial shallowness of the basin might have concurred to build favourable conditions for life. The lack of negative cerium anomalies in the studied cherts is inconsistent with an oxygenated niche in the Buck Reef basin, and supports Tice and Lowe's [2] conclusion for the development of anoxygenic photosynthetic microbial mats.

In the deeper part of the basin $(>200 \mathrm{~m})$ microbial mats were absent and micro-bands were poorly developed, rendering difficult the recognition of varve-like deposits (e.g., Figure 9a). Instead, carbonaceous matter deposited as detrital grains and/or agglomerates, likely derived from shallower 
parts of the system. While settling through the water column, these particles mixed with precipitating silica to form a heterogeneous carbonaceous- and silica-rich mud on the seafloor (Section 4.2).

\subsubsection{Origin of the Coarse Layering: Astronomically-Forced White Chert}

The origin of the massive white chert layers is more enigmatic. They are entirely composed of cryptocrystalline silica, with negligible organic or detrital material; they lack internal structures; and they contain extremely low concentrations of immobile elements, such as the REE and Th, all indicating rapid deposition without continental or organic contributions. What is required is a process that is repeated regularly, probably in tens of thousands of years, in order to explain the alternation between periods of rapid and subdued precipitation of silica recorded in the black and white cherts. We rejected geological or tectonic processes, such as shallowing of the basin; periodic exposure of continental crust and increased riverine input; changes in ocean circulation; and external drivers, such as fluctuations in volcanic outgassing and periods of increased acid rain, because we have difficulty imagining that any of these processes could be repeated with sufficient regularity, hundreds of times. Instead, to explain these features, we call on global events that periodically interrupted the "normal" sedimentation of the black cherts, shut down or overwhelmed external contributions from the continent, and inhibited microbial activity while promoting massive and rapid silica precipitation on the seafloor.

Although the Archean climate is believed to have been generally warm and humid (e.g., [19,91-93] and references therein) glaciation is recorded at 3.0-2.9 Ga in the Pongola Supergroup in South Africa [94] and de Wit and Furnes [95] identified diamictites in the 3.45 Ga Etimambeni section of the Barberton belt, which conformably underlies the felsic lavas beneath the Buck Reef Chert. De Wit et al. [33], Grosch et al. [74] and de Wit and Furnes [70] argue for a moderately cold climate with local glacial conditions as early as $3.4-3.5 \mathrm{Ga}$. The cooler periods did not necessary lead to the development of ice sheets but could have been limited to strong variations of mean surface temperatures, possibly accompanied by significant eustatic variations of sea level and ocean circulation (e.g., $[85,95,96])$.

As a possible cause of the macro-banding illustrated in Figure 16, we invoke major events of the type that perturbed global climate in the recent past and led to the alternation of glacial and interglacial periods. We accept the hypothesis (e.g., $[97,98]$ ) that astronomical factors-the interplay of orbital parameters, mainly precession and obliquity_influenced insolation and that this led to changes in average global temperatures. The magnitude of these changes was only a few degrees but their impact was multiplied by feedback, such as changes in global albedo or patterns of ocean circulation, that resulted in more drastic temperature fluctuations that led to oscillations between glacial and interglacial periods [99-101].

Recent geological history is, again, of limited application to the Archean situation because the Archean world was so different from that of today. In the absence of abundant emergent crust, the large continents that channel today's ocean circulation were missing. The absence of large continents and a rarity of land meant there were fewer influxes of freshwater of the type that are thought to have triggered recent climate perturbations.

On the Archean waterworld, ocean circulation may have been trimodal, with a westward equatorial current sandwiched between two eastward polar currents, as illustrated in the model of Keinert et al. ([99], Figure 17). Because of the high albedo contrast between snow-covered sea ice at the poles and the low-albedo oceans that covered most of the planet, the latitudinal temperature gradient was steep, with a temperature difference of almost $50 \mathrm{~K}$ between latitudes $30^{\circ}$ and $60^{\circ}$. Under these conditions, the minor temperature changes caused by astronomically-forced fluctuations in solar radiation would trigger latitudinal migration of the boundary between ocean circulation currents, provoking major changes not only in temperature but also to other temperature-sensitive parameters. The major flux of fresh water would be from snow deposited on sea ice at the poles. During cold glacial periods, this reservoir grew larger and freshwater flow ceased. During interglacials, increasing temperatures melted the snow, causing an influx of freshwater into the polar oceans, decreasing both the salinity and 
the concentration of dissolved silica. Nascent continents located in temporal zones would have been particularly sensitive to fluctuations in local conditions.
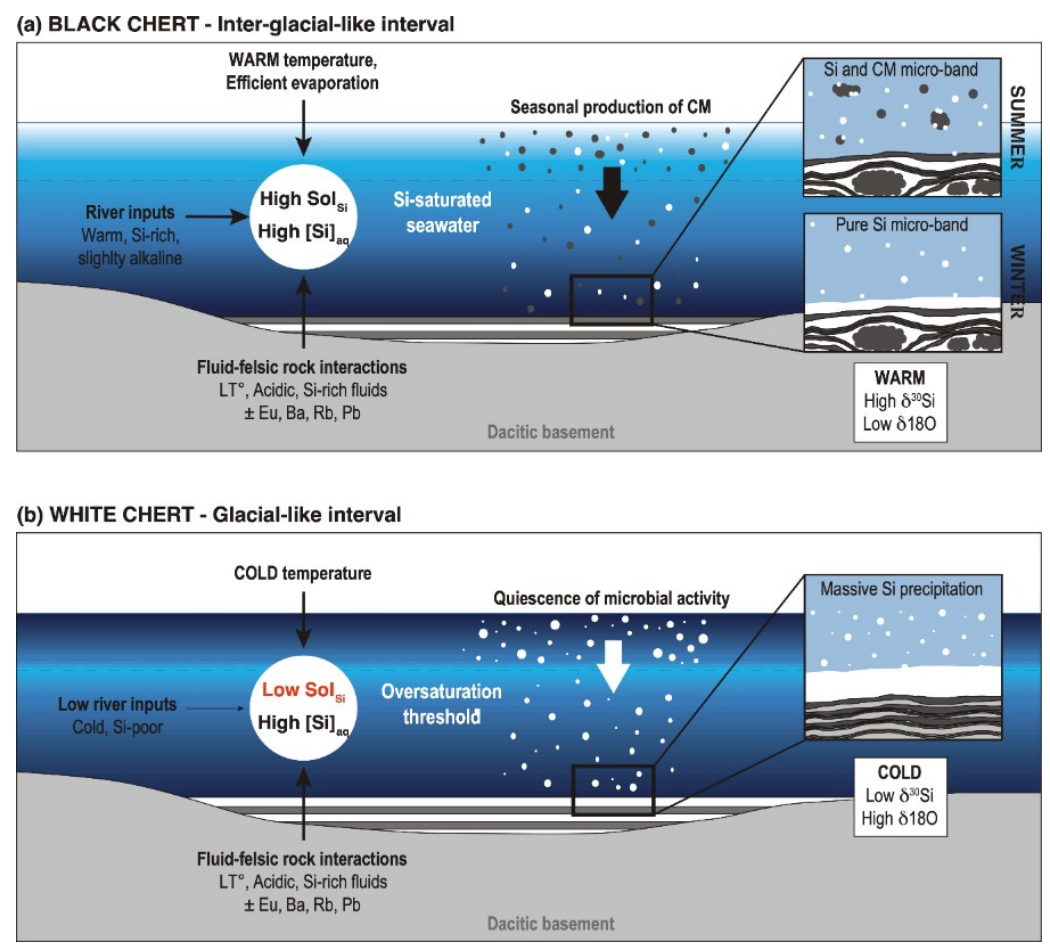

Figure 16. Schematic representation of the climate-forcing hypothesis. (a) During high temperature intervals, warm evaporative conditions, silica inputs from the seafloor and possibly slightly alkaline, Si-rich riverine inputs concur to maintain the shallow basin close to silica saturation. Black chert layers are formed by continuous background silica precipitation and seasonal carbonaceous matter deposition during summer periods. (b) During low temperature intervals, the temperature and $\mathrm{pH}$ drop, which dramatically lowers silica solubility, at least in the shallowest parts of the water column. The basin passes the oversaturation threshold and silica is massively precipitated to form the white chert layers. Microbial communities are in a quiescent state, thus organic matter is absent from the sedimentary record. Isotopic characteristics of the black and white cherts are from Geilert et al. [12].

The solubility of Si in ocean waters depends mainly on temperature and salinity, the effect of $\mathrm{pH}$ being very minor except in very alkaline solutions (e.g., [102,103]). Whether or not silica precipitates also depends on the Si concentration, which influences how far the solution is from silica saturation, and on the activities of marine microorganisms. These factors are relatively well understood in modern ocean waters but are less well known in the Archean ocean. Temperatures may have been higher (e.g., [104]) or very similar to today's [105]. There is general agreement that the acidity was slightly lower but little consensus about oxidation state, salinity and other compositional aspects (e.g., [106-109]). Quantitative information about Si solubility in Archean seawater is sparse, and the role of marine biota, which control the silica content of modern seawater, is virtually unknown. These uncertainties preclude quantitative modelling of the behaviour of silica in Archean oceans, but some inferences can be made.

During the warm periods, migration of circum-equator current towards the poles leads to considerable warming at the junction between the two currents (Figure 17). This warming, combined with the decrease in salinity caused by freshwater influx, inhibited silica precipitation. These conditions would have been favourable for the long-term establishment of microbial communities in shallow basins at the margins of land masses, producing the large amount of organic matter now fossilized in the black cherts. A continuous supply of silica from low-temperature seafloor venting (Section 6.4.1) and high evaporation rates (e.g., $[110,111])$ at the ocean-atmosphere interface, combined to promote 
high silica concentrations within a restricted basin of the type envisaged for the deposition of Buck Reef cherts. While these conditions prevailed, limited sedimentation of silica flocs and silica uptake by biota, combined with growth of microbioal mats at the sediment-water interface, produced the black chert layers.
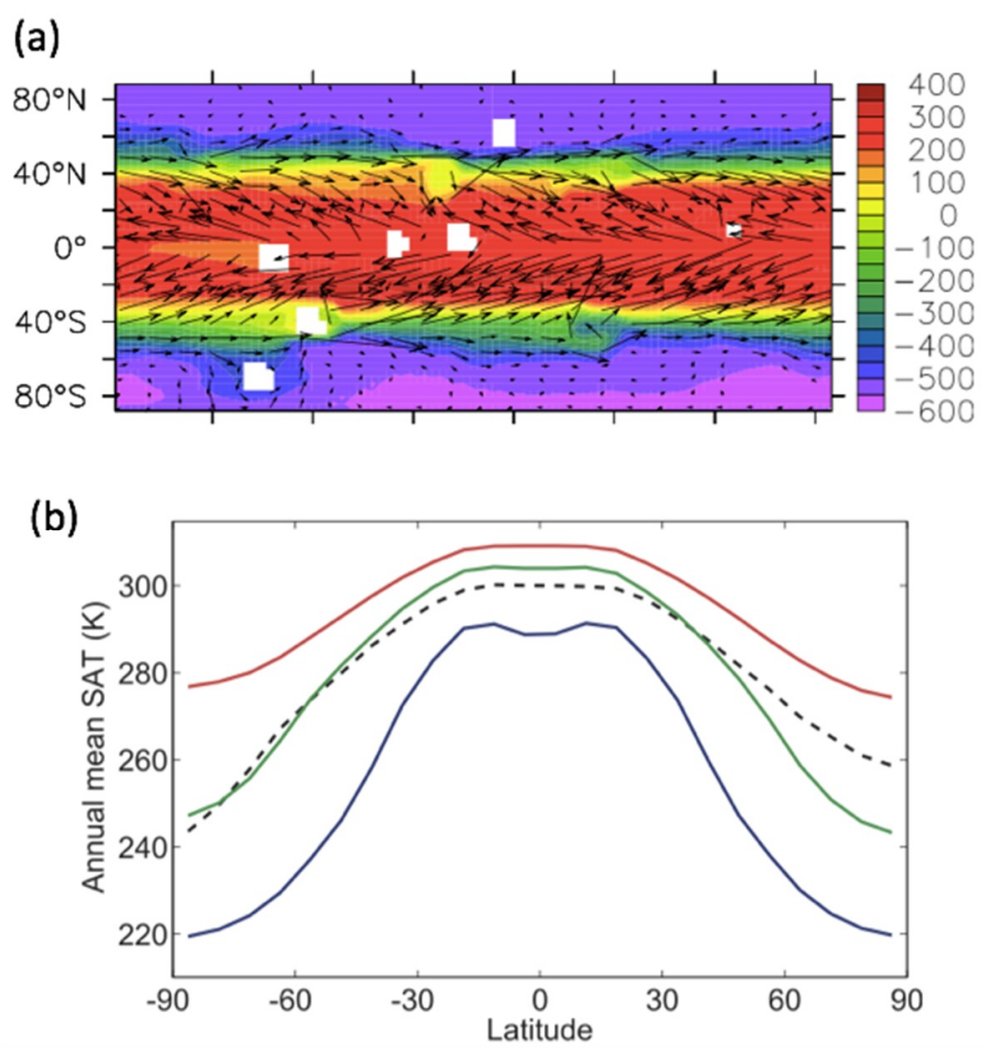

Figure 17. (a) Sketch of Keinert et al.'s [99] model of ocean currents during the Archean. Oceanic surface velocities are indicated by the arrows and colour shading indicates sea surface height anomalies. The white squares represent small continents. (b) Annual and zonal mean surface air temperature (SAT) for the pre-industrial Earth (black), the critical state of the early Archean $\left(\mathrm{pCO}_{2}=0.4\right.$ bar, blue), the state of the early Archean with present-day mean SAT of $288 \mathrm{~K}\left(\mathrm{pCO}_{2}=0.6\right.$ bar, green) and an ice-free state $\left(\mathrm{CO}_{2}=0.8\right.$ bar, red $)$ [99].

A change to a cooler climate would have decreased surface temperatures and arrested freshwater inputs, decreasing the solubility of silica and destabilizing the water column: seawater temporarily passed through its silica saturation level, leading to the sudden and dramatic flocculation and sedimentation of massive amounts of pure silica. At the same time, the biota entered a quiescent period, or they were simply swamped by rapid accumulation of abiogenic silica. Then, a new warm evaporative period allowed the slow recharge in dissolved silica of the surface layer, which lasted until the next climate perturbation.

Climate variations, such as modern glacial/interglacial-like periods, meet the inferred thousand-year periodicity of the banding process. Such a model explains the purity of the white cherts; i.e., their lack of continental input and organic matter, the regularity of the banding and its homogeneous lateral extent. The temperature variations are also consistent with the isotopic fractionation observed between the black and white cherts $[12,17,24,63]$ : assuming a similar origin for the silica, the white layers have lighter $\delta^{30} \mathrm{Si}$ and higher $\delta^{18} \mathrm{O}$ compositions, both indicating cooler conditions during their formation. 


\section{Implications}

A shorter Milankovitch cycle related to periodic axial precession of the Earth could account for the substantial temperature fluctuations proposed here. The periods for precession would have been much shorter during the Archean because of the dynamics of the Earth-Moon system at that time: Lantink et al. [87] calculated two periods, $405 \mathrm{ky}$ and 1.4-1.6 myr at 2.5 Ga; Berger and Loutre [112] envisaged periods of 11.3 and $12.7 \mathrm{kyr}$ also at $2.5 \mathrm{Ga}$, while Ito et al. [113] proposed even shorter periods of 5000 to $7000 \mathrm{yrs}$. The latter estimation, in particular, is consistent with the conditions we infer from the deposition of the $3.4 \mathrm{Ga}$ Buck Reef sequence. If our model is correct and the periodicity of deposition of $B \& W$ cherts can be calibrated, it provides the means to constrain the timing of the Milankovitch cycle and other climate-forcing events in the early history of our planet.

Finally, by providing new evidence for the formation of banded chert units through chemical precipitation from ambient marine fluids, we strengthen the idea that these sediments may be used for paleo-environmental reconstruction. Their chemical composition may have recorded key features of the originally precipitating fluid, perhaps complicated by additional signals from secondary processes such as diagenesis, late-stage silicification, weathering and/or metamorphism.

\section{Conclusions}

From our study of the Buck Reef cherts we conclude:

- The sediment-like contacts between the black and white layers; the high purity of the white bands and their lack of internal structures; and the common reworking of white bands at the surface into slab conglomerates, are all evidence that the banding is not inherited from the silicification of a previously bedded sedimentary precursor, nor was it produced during diagenesis. Instead, we argue that alternating bands of black and white chert were formed by the chemical precipitation of silica and carbonaceous matter on the seafloor from Si-saturated seawater.

- The basin chemistry and silica content were influenced by the seepage of low-temperature fluids that had interacted with felsic volcanics and volcaniclastics beneath the sea floor. Stratigraphic variations and an increasing hydrothermal signal in the cherts resulted from mixing with seawater and progressive deepening of the basin.

- Micro-scale alternations of silica and carbonaceous laminae within the black bands are attributed to seasonal (annual) fluctuations similar to those observed in modern siliceous sinters: white micro-bands formed during winter by abiologic silica precipitation, while microbial activity was inhibited by the cold temperatures; black micro-bands formed during summer, when warmer conditions promoted carbonaceous matter production and the colonization of the euphotic zone by anoxygenic photosynthetic microorganisms.

- The outcrop-scale macro-layering resulted from temperature variations at a much greater timescale, likely associated with glacial/interglacial intervals of a few thousand years periodicity. Warm periods were suitable for black chert formation, and promoted silica solubility and saturated Si content in the restricted basin. During cold intervals, the decrease of surface temperature, freshwater inputs and water $\mathrm{pH}$ led to a drastic decrease of silica solubility: ambient seawater temporarily passed through its saturation level, resulting in the sudden and dramatic flocculation and sedimentation of a massive amount of pure silica. The quiescence of microbial activity at that time explains the remarkable absence of carbonaceous matter in these layers.

Our model provides strong evidence that banded cherts are primary chemical sediments that may be used to investigate surface conditions on the early Earth; however, not only hydrothermal and oceanic paleo-fluid compositions, but also large scale processes, such as the timing of the Milankovitch cycle and other climate-forcing events back in the Archean.

Supplementary Materials: The following are available online at http://www.mdpi.com/2076-3263/9/10/424/s1, S1: Analytical procedures. 
Author Contributions: M.L. did most of the field work, thin section descriptions and geochemical analyses, and wrote most of the paper. N.A. conceived the project and helped with the interpretation. C.C. assisted with geochemical analyses. All authors contributed to the preparation of the manuscript.

Funding: This research was funded by the EPOV program (CNRS) and the ANR project BEGDy (BLAN-0109).

Acknowledgments: For assistance in the lab, we thank Sarah Bureau and Christelle Poggi for geochemical analyses and Valentina Sobolev for microprobe analyses. For the help in the field, we thank Axel Hofmann and Gordon Chunnett.

Conflicts of Interest: The authors declare no conflict of interest.

\section{References}

1. Derry, L.A.; Jacobsen, S.B. The chemical evolution of Precambrian seawater: Evidence from REEs in banded iron formations. Geochim. Cosmochim. Acta 1990, 54, 2965-2977. [CrossRef]

2. Tice, M.M.; Lowe, D.R. The origin of carbonaceous matter in pre-3.0 Ga greenstone terrains: A review and new evidence from the 3.42 Ga Buck Reef Chert. Earth-Sci. Rev. 2006, 76, 259-300. [CrossRef]

3. Frei, R.; Polat, A. Source heterogeneity for the major components of $\sim 3.7$ Ga Banded Iron Formations (Isua Greenstone Belt, Western Greenland): Tracing the nature of interacting water masses in BIF formation. Earth Planet. Sci. Lett. 2007, 253, 266-281. [CrossRef]

4. De Vries, S.T. Early Archaean Sedimentary Basins: Depositional Environment and Hydrothermal Systems. Ph.D. Thesis, Utrecht University, Utrecht, The Netherlands, September 2004; pp. 1-160.

5. De Vries, S.T.; Nijman, W.; De Boer, P. Sedimentary geology of the Palaeoarchean Buck Ridge (South Africa) and Kittys Gap (Western Australia) volcano-sedimentary complexes. Precambrian Res. 2010, 183, 749-769. [CrossRef]

6. De Vries, S.T.; Nijman, W.; Armstrong, R.A. Growth-fault structure and stratigraphic architecture of the Buck Ridge volcano-sedimentary complex, upper Hooggenoeg Formation, Barberton Greenstone Belt, South Africa. Precambrian Res. 2006, 149, 77-98. [CrossRef]

7. Lowe, D.R.; Fisher Worrell, G.F. Sedimentology, mineralogy, and implications of silicified evaporites in the Kromberg Formation, Barbeton Greenstone Belt, South Africa. In Geological Evolution of the Barberton Greenstone Belt, South Africa; Lowe, D.R., Byerly, G.R., Eds.; Geological Society of America: Boulder, CO, USA, 1999; pp. 167-188.

8. Morris, R. Genetic modelling for banded iron-formation of the Hamersley Group, Pilbara Craton, Western Australia. Precambrian Res. 1993, 60, 243-286. [CrossRef]

9. Klein, C. Some Precambrian banded iron-formations (BIFs) from around the world: Their age, geologic setting, mineralogy, metamorphism, geochemistry, and origins. Am. Miner. 2005, 90, 1473-1499. [CrossRef]

10. Steinhoefel, G.; Horn, I.; Von Blanckenburg, F. Micro-scale tracing of Fe and Si isotope signatures in banded iron formation using femtosecond laser ablation. Geochim. Cosmochim. Acta 2009, 73, 5343-5360. [CrossRef]

11. Bontognali, T.R.; Fischer, W.W.; Föllmi, K.B. Siliciclastic associated banded iron formation from the 3.2Ga Moodies Group, Barberton Greenstone Belt, South Africa. Precambrian Res. 2013, 226, 116-124. [CrossRef]

12. Geilert, S.; Vroon, P.Z.; Van Bergen, M.J. Silicon isotopes and trace elements in chert record early Archean basin evolution. Chem. Geol. 2014, 386, 133-142. [CrossRef]

13. Posth, N.R.; Hegler, F.; Konhauser, K.O.; Kappler, A. Alternating Si and Fe deposition caused by temperature fluctuations in Precambrian oceans. Nat. Geosci. 2008, 1, 703-708. [CrossRef]

14. Sugitani, K.; Yamamoto, K.; Adachi, M.; Kawabe, I.; Sugisaki, R. Archean cherts derived from chemical, biogenic and clastic sedimentation in a shallow restricted basin: Examples from the Gorge Creek Group in the Pilbara Block. Sedimentology 1998, 45, 1045-1062. [CrossRef]

15. Kato, Y.; Nakamura, K. Origin and global tectonic significance of Early Archean cherts from the Marble Bar greenstone belt, Pilbara Craton, Western Australia. Precambrian Res. 2003, 125, 191-243. [CrossRef]

16. Bolhar, R.; Van Kranendonk, M.J.; Kamber, B.S. A trace element study of siderite-jasper banded iron formation in the 3.45 Ga Warrawoona Group, Pilbara Craton - Formation from hydrothermal fluids and shallow water. Precambrian Res. 2005, 137, 93-114. [CrossRef]

17. Knauth, L.P.; Lowe, D.R. High Archean climatic temperature inferred from oxygen isotope geochemistry of cherts in the 3.5 Ga Swaziland Supergroup, South Africa. GSA Bull. 2003, 115, 566-580. [CrossRef] 
18. Perry, E.; Lefticariu, L. The oxygen isotopic composition of Precambrian cherts. Geochim. Cosmochim. Acta 2006, 70, A483. [CrossRef]

19. Robert, F.; Chaussidon, M. A palaeotemperature curve for the Precambrian oceans based on silicon isotopes in cherts. Nature 2006, 443, 969-972. [CrossRef] [PubMed]

20. Boorn, S.V.D.; Van Bergen, M.; Vroon, P.; De Vries, S.; Nijman, W. Silicon isotope and trace element constraints on the origin of $\sim 3.5 \mathrm{Ga}$ cherts: Implications for Early Archaean marine environments. Geochim. Cosmochim. Acta 2010, 74, 1077-1103. [CrossRef]

21. Marin, J.; Chaussidon, M.; Robert, F. Microscale oxygen isotope variations in 1.9Ga Gunflint cherts: Assessments of diagenesis effects and implications for oceanic paleotemperature reconstructions. Geochim. Cosmochim. Acta 2010, 74, 116-130. [CrossRef]

22. Marin-Carbonne, J.; Chaussidon, M.; Boiron, M.-C.; Robert, F. A combined in situ oxygen, silicon isotopic and fluid inclusion study of a chert sample from Onverwacht Group (3.35Ga, South Africa): New constraints on fluid circulation. Chem. Geol. 2011, 286, 59-71. [CrossRef]

23. Marin-Carbonne, J.; Chaussidon, M.; Robert, F. Micrometer-scale chemical and isotopic criteria (O and $\mathrm{Si})$ on the origin and history of Precambrian cherts: Implications for paleo-temperature reconstructions. Geochim. Cosmochim. Acta 2012, 92, 129-147. [CrossRef]

24. Stefurak, E.J.; Fischer, W.W.; Lowe, D.R. Texture-specific Si isotope variations in Barberton Greenstone Belt cherts record low temperature fractionations in early Archean seawater. Geochim. Cosmochim. Acta 2015, 150, 26-52. [CrossRef]

25. Viljoen, M.J.; Viljoen, R.P. An introduction to the geology of the Barberton, granite-greenstone terrain. Geol. Soc. S. Afr. Spec. Publ. 1969, 9, 1-20.

26. Armstrong, R.; Compston, W.; De Wit, M.; Williams, I. The stratigraphy of the 3.5-3.2 Ga Barberton Greenstone Belt revisited: A single zircon ion microprobe study. Earth Planet. Sci. Lett. 1990, 101, 90-106. [CrossRef]

27. Kröner, A.; Byerly, G.; Lowe, D.R. Chronology of Early Archean granite-greenstone evolution in the Barberton Mountain Land, South Africa, based on precise dating by signle zircon evaporation. Earth Planet. Sci. Lett. 1991, 103, 41-54. [CrossRef]

28. Kamo, S.L.; Davis, D.W. Reassessment of Archean crustal development in the Barberton Mountain Land, South Africa, based on U-Pb dating. Tectonics 1994, 13, 167-192. [CrossRef]

29. Byerly, G.R.; Kroner, A.; Lowe, D.R.; Todt, W.; Walsh, M.M. Prolonged magmatism and time constraints for sediment deposition in the early Archean Barberton greenstone belt: Evidence from the Upper Onverwacht and Fig Tree groups. Precambrian Res. 1996, 78, 125-138. [CrossRef]

30. Lowe, D.R.; Byerly, G.R. An overview of the geology of the Barberton Greenstone Belt: implications for early crustal development. Dev. Precambrian Geol. 2007, 15, 481-526.

31. Viljoen, M.J.; Viljoen, R.P. The geological and geochemical significance of the upper formations of the Onverwacht Group. Geol. Soc. S. Afr. Spec. Publ. 1969, 2, 113-151.

32. De Wit, M.J.; Furnes, H.; Robins, B. Archaean abiogenic and probable biogenic structures associated with mineralized hydrothermal vent systems and regional metasomatism, with implications for greenstone belt studies. Econ. Geol. 2011, 77, 1783-1802. [CrossRef]

33. Furnes, H.; De Wit, M.J.; Robins, B.; Sandstå, N.R. Volcanic evolution of the upper Onverwacht Suite, Barberton Greenstone Belt, South Africa. Precambrian Res. 2011, 186, 28-50. [CrossRef]

34. Lowe, D.R. Petrology and Sedimentology of Cherts and Related Silicified Sedimentary Rocks in the Swaziland Supergroup; Geological Society of America: Boulder, CO, USA, 1999; pp. 83-114.

35. Walsh, M.M. Microfossils and possible microfossils from the Early Archean Onverwacht Group, Barberton Mountain Land, South Africa. Precambrian Res. 1992, 54, 271-292. [CrossRef]

36. Westall, F. Life on the Early Earth: A Sedimentary View. Science 2005, 308, 366-367. [CrossRef] [PubMed]

37. Tice, M.M.; Lowe, D.R. Photosynthetic microbial mats in the 3,416-Myr-old ocean. Nature 2004, 431, 549-552. [CrossRef] [PubMed]

38. Schieber, J.; Bose, P.K.; Eriksson, P.G.; Banerjee, S.; Sarkar, S.; Altermann, W.; Catuneanu, O. (Eds.) Atlas of Microbial Mat Features Preserved Within the Siliciclastic Rock Record; Elsevier: Amsterdam, The Netherlands, 2007; Volume 2.

39. Chauvel, C.; Bureau, S.; Poggi, C. Comprehensive Chemical and Isotopic Analyses of Basalt and Sediment Reference Materials. Geostand. Geoanal. Res. 2011, 35, 125-143. [CrossRef] 
40. Ledevin, M.; Arndt, N.; Simionovici, A.; Jaillard, E.; Ulrich, M. Silica precipitation triggered by clastic sedimentation in the Archean: New petrographic evidence from cherts of the Kromberg type section, South Africa. Precambrian Res. 2014, 255, 316-334. [CrossRef]

41. Taylor, S.R.; McLennan, S.M. The Continental Crust: Its Composition and Evolution; Hallam, A., Ed.; Blackwell Scientific Publications: Hoboken, NJ, USA, 1985; p. 312.

42. Alibo, D.S.; Nozaki, Y. Rare earth elements in seawater: particle association, shale-normalization, and Ce oxidation. Geochim. Cosmochim. Acta 1999, 63, 363-372. [CrossRef]

43. Douville, E.; Bienvenu, P.; Charlou, J.L.; Donval, J.P.; Fouquet, Y.; Appriou, P.; Gamo, T. Yttrium and rare earth elements in fluids from various deep-sea hydrothermal systems. Geochim. Cosmochim. Acta 1999, 63, 627-643. [CrossRef]

44. Stefurak, E.J.T.; Lowe, D.R.; Zentner, D.; Fischer, W.W. Primary silica granules - A new mode of early Archean sedimentation. Geology 2014, 42, 283-286. [CrossRef]

45. Duchac, K.C.; Hanor, J.S. Origin and timing of the metasomatic silicification of an early archean komatiite sequence, barberton mountain land, South Africa. Precambrian Res. 1987, 37, 125-146. [CrossRef]

46. Hanor, J.S.; Duchac, K.C. Isovolumetric silicification of early Archean Komatities: geochemical mass balances and constraints on origin. J. Geol. 1990, 98, 863-877. [CrossRef]

47. Hofmann, A.; Harris, C. Silica alteration zones in the Barberton greenstone belt: A window into subseafloor processes 3.5-3.3 Ga ago. Chem. Geol. 2008, 257, 221-239. [CrossRef]

48. Orberger, B.; Rouchon, V.; Westall, F.; De Vries, S.T.; Pinti, D.L.; Wagner, C.; Wirth, R.; Hashizume, K. Microfacies and origin of some Archean cherts (Pilbara, Australia), Special Paper 405. Process. Early Earth 2006, 405, 133-156.

49. Rouchon, V.; Orberger, B. Origin and mechanisms of K-Si-metasomatism of ca. 3.4-3.3Ga volcaniclastic deposits and implications for Archean seawater evolution: Examples from cherts of Kittys Gap (Pilbara craton, Australia) and Msauli (Barberton Greenstone Belt, South Africa). Precambrian Res. 2008, 165, 169-189. [CrossRef]

50. Krapež, B.; Barley, M.E.; Pickard, A.L. Hydrothermal and resedimented origins of the precursor sediments to banded iron formation: sedimentological evidence from the Early Palaeoproterozoic Brockman Supersequence of Western Australia. Sedimentology 2003, 50, 979-1011. [CrossRef]

51. Lascelles, D.F. Black smokers and density currents: A uniformitarian model for the genesis of banded iron-formations. Ore Geol. Rev. 2007, 32, 381-411. [CrossRef]

52. Bekker, A.; Slack, J.F.; Planavsky, N.; Krapez, B.; Hofmann, A.; Konhauser, K.O.; Rouxel, O.J. Iron Formation: The Sedimentary Product of a Complex Interplay among Mantle, Tectonic, Oceanic, and Biospheric Processes. Econ. Geol. 2010, 105, 467-508. [CrossRef]

53. Murray, R.W.; Brink, M.R.B.T.; Gerlach, D.C.; Russ, G.P.; Jones, D.L. Rare earth, major, and trace element composition of Monterey and DSDP chert and associated host sediment: Assessing the influence of chemical fractionation during diagenesis. Geochim. Cosmochim. Acta 1992, 56, 2657-2671. [CrossRef]

54. Egglseder, M.; Cruden, A.; Tomkins, A.; Wilson, S.; Langendam, A. Colloidal origin of microbands in banded iron formations. Geochem. Perspect. Lett. 2018, 6, 43-49. [CrossRef]

55. Dhuime, B.; Hawkesworth, C.J.; Cawood, P.A.; Storey, C.D. A Change in the Geodynamics of Continental Growth 3 Billion Years Ago. Science 2012, 335, 1334-1336. [CrossRef]

56. Bounama, C.; Franck, S.; von Bloh, W. The fate of the Earth's ocean. Hydrol. Earth Syst. Sci. 2001, 5, 569-575. [CrossRef]

57. Bolhar, R.; Kamber, B.S.; Moorbath, S.; Fedo, C.M.; Whitehouse, M.J. Characterization of early Archaean chemical sediments by trace element signatures. Earth Planet. Sci. Lett. 2004, 222, 43-60. [CrossRef]

58. Kamber, B.S.; E Webb, G. The geochemistry of late Archaean microbial carbonate: implications for ocean chemistry and continental erosion history. Geochim. Cosmochim. Acta 2001, 65, 2509-2525. [CrossRef]

59. Klein, C.; Beukes, N.J. Geochemistry and sedimentology of a facies transition from limestone to iron-formation deposition in the early Proterozoic Transvaal Supergroup, South Africa. Econ. Geol. 1989, 84, 1733-1774. [CrossRef]

60. Arndt, N.T.; Nisbet, E.G. Processes on the Young Earth and the Habitats of Early Life. Annu. Rev. Earth Planet. Sci. 2012, 40, 521-549. [CrossRef]

61. Hren, M.T.; Tice, M.M.; Chamberlain, C.P. Oxygen and hydrogen isotope evidence for a temperate climate 3.42 billion years ago. Nature 2009, 462, 205-208. [CrossRef] 
62. De Vries, S.T.; Touret, J.L. Early Archaean hydrothermal fluids; a study of inclusions from the $\sim 3.4$ Ga Buck Ridge Chert, Barberton Greenstone Belt, South Africa. Chem. Geol. 2007, 237, 289-302. [CrossRef]

63. Bau, M. Scavenging of dissolved yttrium and rare earths by precipitating iron oxyhydroxide: experimental evidence for Ce oxidation, Y-Ho fractionation, and lanthanide tetrad effect. Geochim. Cosmochim. Acta 1999, 63, 67-77. [CrossRef]

64. Heinrichs, T. Lithostratigraphische Untersuchungen in der Fig Tree Gruppe des Barberton Greenstone Belt zwischen Umsoli und Lomati (Südafrika). Göttinger Arb. Geol. Paläont. 1980, 22, 118.

65. Nocita, B.W.; Lowe, D.R. Foreland basin sedimentation in the Mapepe Formation, southern-facies Fig Tree Group. In Geologic Evolution of the Barberton Greenstone Belt, South Africa; Special Paper 329; Geological Society of America: Boulder, CO, USA, 1999; pp. 233-258.

66. Nijman, W.; de Bruijne, K.C.; Valkering, M.E. Growth fault control of Early Archaean cherts, barite mounds and chert-barite veins, North Pole Dome, Eastern Pilbara, Western Australia. Precambrian Res. 1998, 88, 25-52. [CrossRef]

67. Herzig, P.M.; Becker, K.P.; Stoffers, P.; Backer, H.; Blum, N. Hydrothermal silica chimney fields in the Galapagos spreading center at 86 degrees W. Earth Planet. Sci. Lett. 1988, 89, 261-272. [CrossRef]

68. Stüben, D.; Taibi, N.; McMurtry, G.M.; Scholten, J.; Stoffers, P.; Zhang, D. Growth history of a hydrothermal silica chimney from the Mariana backarc spreading center (southwest Pacific, $18^{\circ} 13^{\prime} \mathrm{N}$ ). Chem. Geol. 1994, 113, 273-296. [CrossRef]

69. Wang, J.; Chen, D.; Wang, D.; Yan, D.; Zhou, X.; Wang, Q. Petrology and geochemistry of chert on the marginal zone of Yangtze Platform, western Hunan, South China, during the Ediacaran-Cambrian transition. Sedimentology 2012, 59, 809-829. [CrossRef]

70. De Wit, M.J.; Furnes, H. 3.5-Ga hydrothermal fields and diamictites in the Barberton Greenstone Belt-Paleoarchean crust in cold environments. Sci. Adv. 2016, 2, e1500368. [CrossRef] [PubMed]

71. Binns, R.; Barriga, F.; Miller, D. Leg 193 Synthesis: Anatomy of an Active Felsic-Hosted Hydrothermal System, Eastern Manus Basin, Papua New Guinea. In Proceedings of the Proceedings of the Ocean Drilling Program, 194 Scientific Results; International Ocean Discovery Program (IODP): College Station, TX, USA, 2007; Volume 193.

72. Abraham, K.; Hofmann, A.; Foley, S.; Cardinal, D.; Harris, C.; Barth, M.; Andre, L.; Foley, S.; Barth, M. Coupled silicon-oxygen isotope fractionation traces Archaean silicification. Earth Planet. Sci. Lett. 2011, 301, 222-230. [CrossRef]

73. Boorn, S.H.V.D.; Van Bergen, M.J.; Nijman, W.; Vroon, P.Z. Dual role of seawater and hydrothermal fluids in Early Archean chert formation: Evidence from silicon isotopes. Geology 2007, 35, 939. [CrossRef]

74. Grosch, E.; Košler, J.; McLoughlin, N.; Drost, K.; Sláma, J.; Pedersen, R.; Grosch, E. Paleoarchean detrital zircon ages from the earliest tectonic basin in the Barberton Greenstone Belt, Kaapvaal craton, South Africa. Precambrian Res. 2011, 191, 85-99. [CrossRef]

75. Cloud, P. Paleoecological Significance of the Banded Iron-Formation. Econ. Geol. 1973, 68, 1135-1143. [CrossRef]

76. Laschet, C. On the origin of cherts. Facies 1984, 10, 257-289. [CrossRef]

77. Hamade, T.; Konhauser, K.O.; Raiswell, R.; Goldsmith, S.; Morris, R.C. Using Ge/Si ratios to decouple iron and silica fluxes in Precambrian banded iron formations. Geology 2003, 31, 35. [CrossRef]

78. Basile-Doelsch, I.; Meunier, J.D.; Parron, C. Another continental pool in the terrestrial silicon cycle. Nature 2005, 433, 399-402. [CrossRef] [PubMed]

79. Alexander, B.W.; Bau, M.; Andersson, P.; Dulski, P. Continentally-derived solutes in shallow Archean seawater: Rare earth element and $\mathrm{Nd}$ isotope evidence in iron formation from the 2.9Ga Pongola Supergroup, South Africa. Geochim. Cosmochim. Acta 2008, 72, 378-394. [CrossRef]

80. Hannington, M.D.; Scott, S.D. Mineralogy and geochemistry of a hydrothermal silica-sulfide-sulfate spire in the caldera of Axial Seamount, Juan de Fuca Ridge. Can. Mineral. 1988, 26, 603-625.

81. Halbach, M.; Halbach, P.; Lüders, V. Sulfide-impregnated and pure silica precipitates of hydrothermal origin from the Central Indian Ocean. Chem. Geol. 2002, 182, 357-375. [CrossRef]

82. Trendall, A.F.; Blockley, J.G. The Iron Formations of the Precambrian Hamersley Group, Western Australia; Geological Survey of Western Australia: Perth, Australia, 1970; Bulletin 119; p. 366.

83. Williams, G.E. Geological constraints on the Precambrian history of Earth's rotation and the Moon's orbit. Rev. Geophys. 2000, 38, 37-59. [CrossRef] 
84. Barley, M.E.; Pickard, A.L.; Sylvester, P.J. Emplacement of a large igneous province as a possible cause of banded iron formation 2.45 billion years ago. Nature 1997, 385, 55-58. [CrossRef]

85. Pickard, A.L.; Barley, M.E.; Krapež, B. Deep-marine depositional setting of banded iron formation: sedimentological evidence from interbedded clastic sedimentary rocks in the early Palaeoproterozoic Dales Gorge Member of Western Australia. Sediment. Geol. 2004, 170, 37-62. [CrossRef]

86. Konhauser, K.O.; Newman, D.K.; Kappler, A. The potential significance of microbial Fe(III) reduction during deposition of Precambrian banded iron formations. Geobiology 2005, 3, 167-177. [CrossRef]

87. Lantink, M.L.; Davies, J.H.F.L.; Mason, P.R.D.; Schaltegger, U.; Hilgen, F.J. Climate control on banded iron formations linked to orbital eccentricity. Nat. Geosci. 2019, 12, 369-374. [CrossRef] [PubMed]

88. Hüneke, H.; Mulder, T. Deep-Sea Sediments. Dev. Sedimentol. 2011, 63, 849.

89. Konhauser, K.O.; Phoenix, V.R.; Bottrell, S.H.; Adams, D.G.; Head, I.M. Microbial-silica interactions in Icelandic hot spring sinter: Possible analogues for some Precambrian siliceous stromatolites. Sedimentology 2001, 48, 415-433. [CrossRef]

90. Blake, R.E.; Chang, S.J.; Lepland, A. Phosphate oxygen isotopic evidence for a temperate and biologically active Archean ocean. Nature 2010, 464, 1029-1032. [CrossRef] [PubMed]

91. Eriksson, P.; Condie, K.; Tirsgaard, H.; Mueller, W.; Altermann, W.; Miall, A.; Aspler, L.; Catuneanu, O.; Chiarenzelli, J. Precambrian clastic sedimentation systems. Sediment. Geol. 1998, 120, 5-53. [CrossRef]

92. Ohmoto, H. Archean atmosphere, hydrosphere, and biosphere. In The Precambrian Earth: Tempos and Events; Eriksson, P.A., Altermann, D.R., Nelson, D.R., Mueller, W.U., Catuneanu, O., Eds.; Elsevier: Amsterdam, The Netherlands, 2004; pp. 361-387.

93. Hessler, A.M.; Lowe, D.R. Weathering and sediment generation in the Archean: An integrated study of the evolution of siliciclastic sedimentary rocks of the 3.2Ga Moodies Group, Barberton Greenstone Belt, South Africa. Precambrian Res. 2006, 151, 185-210. [CrossRef]

94. Von Brunn, V.; Gold, D.J.D. Diamictite in the Archean Pongola sequence of southern Africa. J. Afr. Earth Sci. 1993, 16, 367-374. [CrossRef]

95. Simonson, B.M.; Hassler, S.W. Was the Deposition of Large Precambrian Iron Formations Linked to Major Marine Transgressions? J. Geol. 1996, 104, 665-676. [CrossRef]

96. Hofmann, A.; Dirks, P.H.G.M.; Jelsma, H.A. Shallowing-upward carbonate cycles in the Bellingwe greenstone belt, Zimbabwe: A record of Archean sea-level oscillations. J. Sediment. Res. 2004, 74, 64-81. [CrossRef]

97. Huybers, P.; Curry, W. Links between annual, Milankovitch and continuum temperature variability. Nature 2006, 441, 329-332. [CrossRef] [PubMed]

98. Jouzel, J.; Masson-Delmotte, V.; Cattani, O.; Dreyfus, G.; Falourd, S.; Hoffmann, G.; Minster, B.; Nouet, J.; Barnola, J.M.; Chappellaz, J.; et al. Orbital and Millennial Antarctic Climate Variability over the Past 800,000 Years. Science 2007, 317, 793-796. [CrossRef] [PubMed]

99. Kienert, H.; Feulner, G.; Petoukhov, V. Albedo and heat transport in 3-D model simulations of the early Archean climate. Clim. Past 2013, 9, 1841-1862. [CrossRef]

100. Bakun, A.; Black, B.A.; Bograd, S.J.; García-Reyes, M.; Miller, A.J.; Rykaczewski, R.R.; Sydeman, W.J. Anticipated Effects of Climate Change on Coastal Upwelling Ecosystems. Curr. Clim. Chang. Rep. 2015, 1, 85-93. [CrossRef]

101. Wang, D.; Gouhier, T.C.; Menge, B.A.; Ganguly, A.R. Intensification and spatial homogenization of coastal upwelling under climate change. Nature 2015, 518, 390-394. [CrossRef] [PubMed]

102. Okamoto, G.; Okura, T.; Goto, K. Properties of Silica in Water. Geochim. Cosmochim. Acta 1957, 12, $123-132$. [CrossRef]

103. Loucaides, S.; Van Cappellen, P.; Behrends, T. Dissolution of biogenic silica from land to ocean: Role of salinity and pH. Limnol. Oceanogr. 2008, 53, 1614-1621. [CrossRef]

104. Tartèse, R.; Chaussidon, M.; Gurenko, A.; Delarue, F.; Robert, F. Warm Archean oceans reconstructed from oxygen isotope composition of early-life remnants. Geochem. Persp. Let. 2017, 3, 55-65. [CrossRef]

105. Krissansen-Totton, J.; Arney, G.N.; Catling, D.C. Constraining the climate and ocean pH of the early Earth with a geological carbon cycle model. Proc. Natl. Acad. Sci. 2018, 115, 4105-4110. [CrossRef]

106. Anbar, A.D.; Knoll, A.H. Proterozoic Ocean Chemistry and Evolution: A Bioinorganic Bridge? Science 2002, 297, 1137-1142. [CrossRef]

107. Knauth, L.P. Temperature and salinity history of the Precambrian ocean: implications for the course of microbial evolution. Geobiol. Object. Concept. Perspect. 2005, 219, 53-69. 
108. Satkoski, A.M.; Beukes, N.J.; Li, W.; Beard, B.L.; Johnson, C.M. A redox-stratified ocean 3.2 billion years ago. Earth Planet. Sci. Lett. 2015, 430, 43-53. [CrossRef]

109. Marty, B.; Avice, G.; Bekaert, D.V.; Broadley, M.W. Salinity of the Archaean oceans from analysis of fluid inclusions in quartz. Comptes Rendus Geosci. 2018, 350, 154-163. [CrossRef]

110. Siever, R. The silica cycle in the Precambrian. Geochim. Cosmochim. Acta 1992, 56, 3265-3272. [CrossRef]

111. Maliva, R.G.; Knoll, A.H.; Simonson, B.M. Secular change in the Precambrian silica cycle: Insights from chert petrology. GSA Bull. 2005, 117, 835. [CrossRef]

112. Berger, A.; Loutre, M.F. Astronomical forcing through geological time. Spec. Publis Int. Ass. Sediment. 1994, 19, 15-24.

113. Ito, T.; Kumazawa, M.; Hamano, Y.; Matsui, T.; Masuda, K. Long Term Evolution of the Solar Insolation Variation over 4Ga. Proc. Jpn. Acad. Ser. B 1993, 69, 233-237. [CrossRef]

(C) 2019 by the authors. Licensee MDPI, Basel, Switzerland. This article is an open access article distributed under the terms and conditions of the Creative Commons Attribution (CC BY) license (http://creativecommons.org/licenses/by/4.0/). 